\title{
Mapping the Research Landscape of Nature-Based Solutions in Urbanism
}

\author{
Lei Li $^{1}\left(\mathbb{D}\right.$, Ali Cheshmehzangi ${ }^{2,3, * \mathbb{D}}$, Faith Ka Shun Chan ${ }^{1,4,5}$ and Christopher D. Ives ${ }^{6}$ (D) \\ 1 School of Geographical Sciences, Faculty of Science and Engineering, University of Nottingham Ningbo \\ China, Ningbo 315000, China; zy13104@nottingham.edu.cn (L.L.); faith.chan@nottingham.edu.cn (F.K.S.C.) \\ 2 Department of Architecture and Built Environment, Faculty of Science and Engineering, University of \\ Nottingham Ningbo China, Ningbo 315100, China \\ 3 Network for Education and Research on Peace and Sustainability (NERPS), Hiroshima University, A601, \\ 1-3-1, Kagamiyama Higashi-Hiroshima City, Hiroshima 739-8530, Japan \\ 4 School of Geography, University of Leeds, Leeds LS2 9JT, UK \\ 5 Water@Leeds Research Institute, University of Leeds, Leeds LS2 9JT, UK \\ 6 School of Geography, University of Nottingham, University Park, Nottingham NG7 2RD, UK; \\ Chris.Ives@nottingham.ac.uk \\ * Correspondence: Ali.Cheshmehzangi@nottingham.edu.cn
}

check for updates

Citation: Li, L.; Cheshmehzangi, A.; Chan, F.K.S.; Ives, C.D. Mapping the Research Landscape of Nature-Based Solutions in Urbanism. Sustainability 2021, 13, 3876. https://doi.org/ $10.3390 /$ su13073876

Academic Editors: Irene Petrosillo and Jakub Brom

Received: 19 January 2021

Accepted: 25 March 2021

Published: 1 April 2021

Publisher's Note: MDPI stays neutral with regard to jurisdictional claims in published maps and institutional affiliations.

Copyright: (c) 2021 by the authors. Licensee MDPI, Basel, Switzerland. This article is an open access article distributed under the terms and conditions of the Creative Commons Attribution (CC BY) license (https:/ / creativecommons.org/licenses/by/ $4.0 /)$.

\begin{abstract}
Nature-based solutions (NBS) are an innovative concept that mimics the processes of natural ecosystems, popularized principally in the European Union. With a substantial body of literature amassed since the term's inception in 2015, there is a need to systematically review existing literature to identify overarching gaps and trends, according to disciplinary focus, geographic scope, and key themes, and direct future research inquiry and policy recommendations. This review consists of bibliometric analysis and thematic analysis for NBS studies in urbanism. NBS studies were found to relate strongly with other concepts of 'Ecosystem Services', 'Green Infrastructure', 'Climate Change', and 'Risk management and Resilience', which align with four major thematic goals set by the European Commission. Within NBS scholarship, various sub-themes have emerged, namely, 'Greening', ‘Urban Development', 'Water', 'Wellbeing', and 'Governance'. Furthermore, we illustrate that the amount and thematic focus of NBS research have been unevenly distributed worldwide. Analysis of emerging trends shows a recent increase in topics, such as adaptive governance of NBS, and the incorporation of social justice in sustainability transitions. Based on an assessment of extant NBS literature, we offer some recommendations for the future direction of the research fields.
\end{abstract}

Keywords: nature-based solutions; sustainable urban development; green infrastructure; ecosystem services; climate change; adaptive governance

\section{Introduction}

Rapid urbanization and climate change are two global trends that are predicted to shape society and the biosphere in the coming decades [1]. Planning and designing cities to address climate change risks (e.g., floods and heatwaves) and social challenges (e.g., public health stress, poverty, and inequity), has become increasingly important. In response, scholars and practitioners have proposed that protecting and restoring ecosystems and enhancing ecosystem services provision could be an effective way to combat such challenges. Consequently, ecosystem-based management has become increasingly important in climate change policy and has contributed to the recent emergence of nature-based solutions (NBS). Since the concepts of sustainability, biodiversity, ecosystem services, and climate change were popular scientific research areas, the NBS concept was proposed with the European Union Horizon 2020 call in 2015. Although it had been presented in academic literature from the mid-2000s, as early as in 2015, the Paris Agreement on Climate Change realized that the 'NBS' concept was a vital tool for meeting global goals on Climate Change and Sustainable Development. The Paris Agreement signatories further revised the Nationally 
Determined Contributions for 2020 that $65 \%$ of signatories involved NBS actions in their Nationally Determined Contributions (NDCs) [2]. The increasing recognition of the NBS approach has contributed to the global policy frameworks, namely, Convention on Biological Diversity (2014), the Sendai Framework for Disaster Risk Reduction (2015), and the "Ramsar Convention" on Wetlands (2015) [2].

Over the past six years, NBS has grown into a widely-adopted term that encompassed concepts of achieving sustainable, harmonious, and green development, and synergized human and environmental outcomes [2]. It was defined by the International Union for Conservation of Nature (IUCN) (2016) as "actions to protect, sustainably manage, and restore natural or modified ecosystems, that address societal challenges effectively and adaptively, simultaneously providing human well-being (sic) and biodiversity benefits, with climate change, food security, disaster risks, water security, social and social and economic development as well as human health being the common societal challenges". NBS explicitly emphasized the importance of nature and ecology, with the European Commission, considering NBS as "inspired and supported by nature, providing environmental, social and economic benefits and help build resilience cost-effectively" [3]. In doing so, NBS was characterized by incorporating biodiversity conservation priorities with socioeconomic development, poverty alleviation, human wellbeing, and planning principles [4], namely, place-specificity, evidence base, integration, equity, and transdisciplinary, that may enhance the likelihood of successful implementation [5].

Accordingly, the NBS concept acted as a bridge between different research fields and between various actors and stakeholders (i.e., policymakers, researchers, and practitioners) through its emphasis on applied sustainable outcomes. The current state of NBS knowledge encompasses research from within and between a range of disciplines, such as some urban foci ideologies on ecology, hydrology, sociology, and planning perspectives. As a potential umbrella concept, NBS closely built on various well-established concepts, which have been explicitly mentioned in policy instruments at European Union and Member States level, namely, 'ecosystem protection approaches', 'ecosystem-based management approaches' and 'ecosystem restoration approaches', 'issue-specific ecosystem-related approaches', and 'infrastructure-related approaches' [2,6-9]. They have gained increasing attention in academic research and policymaking [10]. Ecosystem services, natural capital, and "lessons from nature" could all be put under the open concepts of NBS [6]. These relevant concepts are often considering short-term benefits to human and social-economic perspectives [11], whilst NBS emphasizes the long-term benefits to the human and environment itself in a sustainable manner [4].

NBS has been attracted increased attention in recent years, for example, as a prioritized program since 2013 by IUCN and in the European Union's Horizon 2020 Research Program [12]. In 2014, the European Commission launched a specific working group to support the application of NBS and the connection of nature with cities. A survey about citizens' views and perceptions of 'Nature in Cities' was conducted for further insight in 2015. Moreover, the Renovation and Research agenda for NBS was developed in 2016-2017 by European Commission to cultivate a community with interdisciplinary stakeholders, share good practices in this area to help improve the evidence base and the implementation capacity of NBS [7]. Recent workshops in 2019 and 2020 outlining EU-funded NBS projects identified the breadth of NBS research as covering themes of 'biodiversity', 'climate change mitigation (carbon sequestration and energy reduction)', 'flood mitigation' and 'coastal resilience', 'water quality', 'air quality and microclimate', and 'sustainable communities'. Given the conceptual overlap of NBS with other related environmental concepts, there is a need to understand the 'landscape' of NBS research over the past five years, prior to identifying current and emerging trends that allow scholars and practitioners to navigate and consolidate existing knowledge.

Cities are regarded as important actors in achieving global targets for climate change in the Paris Agreement signed in 2016 [13]. The use of grey infrastructure has dominated urban development, while NBS was emerging in cities, taking advantage of the natural properties of ecosystems. In the urban context, 'infrastructure-related approaches', mainly 
green infrastructure was dominant in the research and implementation. Examples of green roofs and urban green parks reduce urban heat stress; vegetation and rain gardens intercept stormwater; city lagoons and wetlands store permeable surface water. Under the framework of NBS, some actions in cities were researched, such as the preservation of soil [14], and watersheds [15-17], the protection of biodiversity [18,19], the improvement of air quality [20,21], the reduction of greenhouse gas [22], and the reclamation of land for increasing green space $[23,24]$. NBS are intended to make cities locally adapted, resourceefficient, and systemic intervened by bringing more natural features and processes. This is perceived as the overarching perspective of governing cities and environments adaptively for a sustainable future.

To synthesize existing knowledge on NBS and their environmental, social and economic impacts, extensive literature reviews have been carried out. Seventeen reviews specifically focused on NBS have been published since 2017, covering themes of 'public health' [25,26], 'urban redevelopment and regeneration' [27], 'urban agriculture' [28], 'built environment' [29], 'urban greening' [23], 'urban resilience' [30], 'water systems' (e.g., hydro-meteorological risk and urban pluvial flood risk) [31-33], and 'tourisms' [34]. Escobedo et al. (2019) [35] reviewed the relationships among relevant NBS concepts of urban forests, ecosystem services, and green infrastructure. Besides these, governance on NBS, such as 'key enablers and barriers to the implementation of NBS' [36], 'stakeholder engagement' [37], has started to gain more interest. However, there is a need for a comprehensive and systematic review that combines both network and thematic analysis and encompasses the full breadth of NBS literature.

In this review, we assessed the NBS literature in urbanism more comprehensively and systematically to open a wider discussion on how cities can effectively mainstream NBS to achieve diverse thematic goals. We utilized a systematic review approach, including bibliometric analysis, and followed with thematic analysis to contribute to the understanding of NBS in urban planning and identifying research gaps. The bibliometric analysis based on network analysis was used because it is an efficient technique to map knowledge visually, identify research gaps and explore new areas. Network analysis was originated based on the seminal works of Garfield, who proposed academic literature citation indexing explicitly and formally [38], and applied in various fields since then. For example, social studies [39-41], biology [42], and medicine [43-45] have most commonly utilized this approach. It has become increasingly important to analyze environmental issues, such as ecological networks [46,47], strategic environment assessment [48], environmental governance [49], climate change mitigation and adaptation [50] (e.g., greenhouse gas mitigation [51]), and more especially, sponge city [52], and urban green infrastructure [53]. These elements can be considered under the umbrella of the NBS concept in recent years.

The existing challenges are interacting with the NBS concept, and its application in urbanism include the inadequate synergies in urban land use and planning to align with environmental, social, and economic goals [1], the vague understating to NBS with relevant concepts [35], the unequal research and distribution of practice in different nations and disciplines [35,54], and the insufficient research on the suitable governance approaches for NBS [55].

Therefore, we aim to map and evaluate the existing NBS literature to address these challenges and identify future research directions and policy implications. We pursue the following three specific research objectives:

(1) Understand the associations between NBS and related concepts, themes, and their implications for concept evolution and sector cooperation;

(2) Identify the up-to-date research foci, trends, and gaps of NBS studies in urbanism by analyzing its disciplinary focus, geographic scope, study methods, and funding sources;

(3) Discuss the governance approaches of NBS and provide recommendations for decisionmakers and researchers. 
In this paper, we first illustrate the methodology, including bibliometric and thematic analysis in Section 2 to achieve Objectives 1 and 2. The corresponding results of these two analyses are presented in Sections 3.1 and 3.2. Next, we discuss NBS as an umbrella and boundary concept for related terms to answer Objective 1 in Section 4.1. The implications among geographic scope, funding support, and thematic goals to answer Objective 2 in Section 4.2. We then deduce that the governance of NBS was one of the emerging themes from the results in Sections 3.1 and 3.2. Therefore, the way forward to improving the governance approaches of NBS in urbanism governance is discussed in Section 4.3 to answer Objective 3. Finally, the conclusion of this review, along with four recommendations for future research and policy insights, are proposed in Section 5.

\section{Methods}

The research approach consisted of four procedures: (1) Paper searching, screening, and selection; (2) bibliometric analysis of included papers; (3) thematic analysis of included papers; and (4) recommendations for future research. The following three sub-sections elaborated each step.

Figure 1. Schematic diagram of this was presented explicitly in Figure 1 to show the connections between research methodology, objectives, and findings in the corresponding subsequent sections.

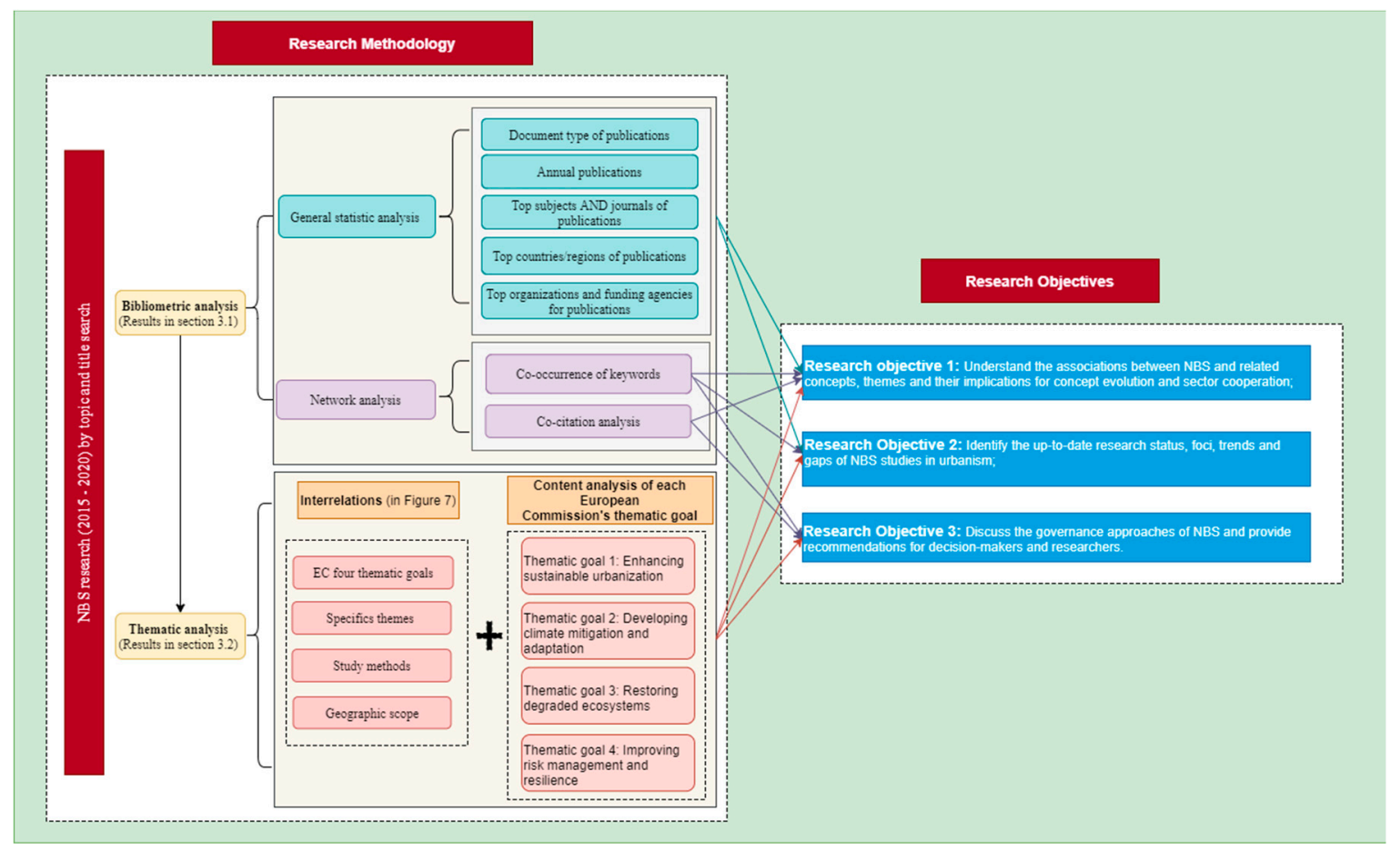

Figure 1. Schematic diagram of this review (Source: authors).

\subsection{Search Strategy and Selection Criteria of Literature}

In this section, we described how we conducted our literature search and the procedure we used to select the reviewed literature.

\subsubsection{Data Collection and Identification}

This study employed an extensive search strategy to locate relevant published studies by a computer search. The Web of Science (WOS) was used because it is the largest and inclusive academic database with more than 8700 core academic journals and seven databases [56,57]. WOS provides a platform to share comprehensive, formats uniformed, and academic references. WOS was supplemented by relevant reports by organizations 
involved with implementing NBS, such as World Bank, IUCN, and European Commission. The process of literature searching and analysis was depicted in the PRISMA flowchart [58], shown in Figure 2. The first step of this systematic analysis was to develop a robust search string to ensure all related papers were captured.

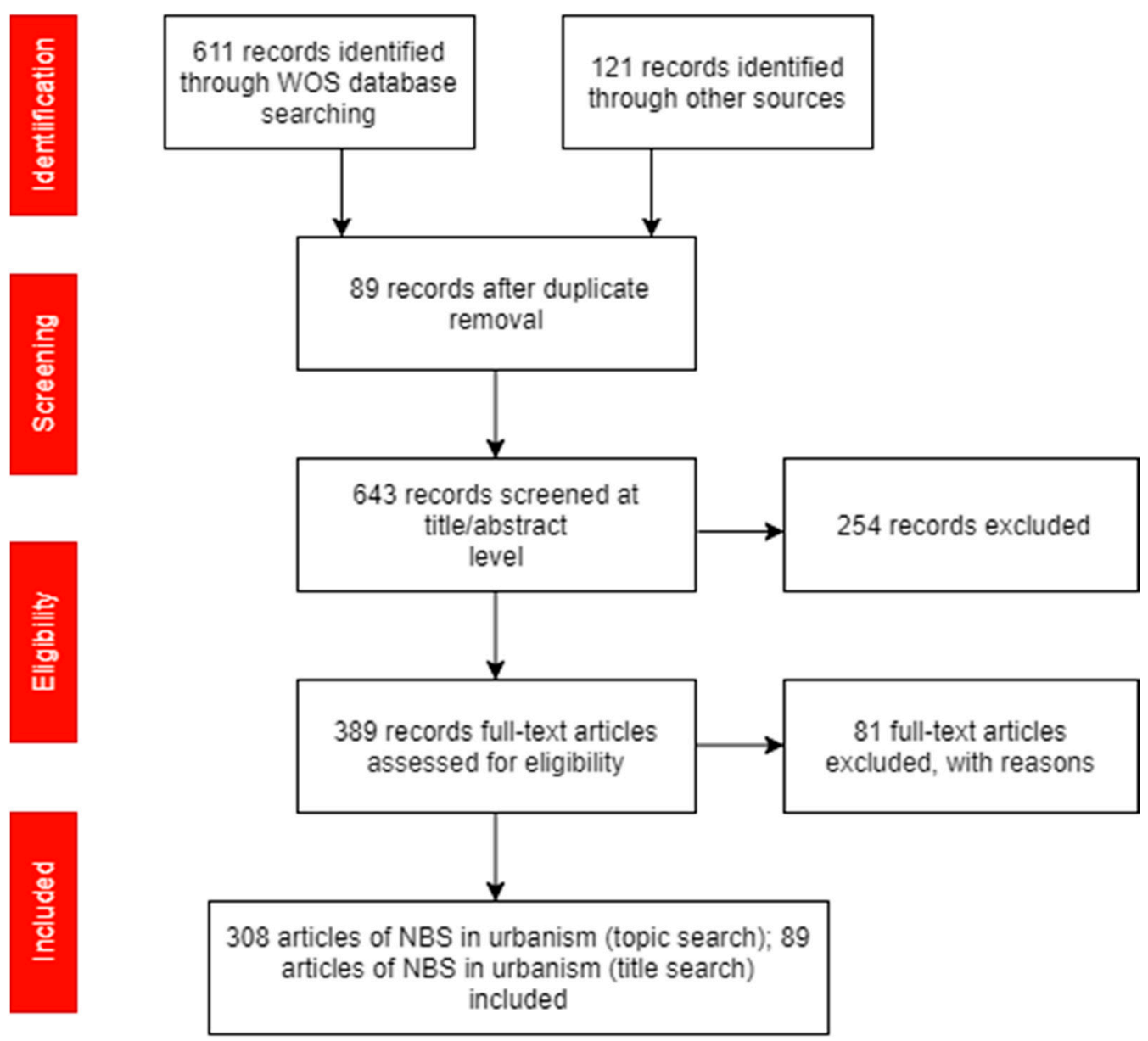

Figure 2. Flowchart of the whole selection process of nature-based solutions (NBS) papers in urbanism (by topic search generally included and title search specifically focused) (the selection procedure was adopted from Moher et al., 2009) [58].

First, a keyword search based on the topic of 'Nature-Based Solutions"' and then with the combination with other related keywords, 'Nature-Based Solutions* AND (urban OR $\left(i t y^{*}\right)^{\prime}$ in advanced research, which means the studies of NBS in urbanism, hereby aligning our search profile that merged with the major study aim. Second, a keyword search of title included 'Nature-Based Solutions ${ }^{* \prime}$ in the (urban OR city*) context in advanced research was conducted. The years in which specific keywords were searched for papers were not limited. The findings revealed the timeframe from the start of 2015 to the end of October 2020, which indicated the first five-year timeframe of the NBS research publications.

The reference lists were be checked using the iterative process (snowball method) consisting of the identification of synonymous terms. We repeated this iterative cycle of searching, reviewing, and selecting relevant papers several times from October 2019 to October 2020, given that the topic is dynamic and new. During each iteration, we enriched our review database with new identified papers.

\subsubsection{Screening and Eligibility}

The second step was considered 'screening', which included screening the papers according to designed inclusion and exclusion criteria. The inclusion criteria were (1) NBS was the main focus of investigation rather than only referred the term in the introduction 
or discussion part; (2) the paper was written in English; (3) papers with peer-review published between 2015 and 2020. The exclusion criteria were applied to (1) the publications containing correct terms, but discussing unrelated topics were excluded, such as mathematics, neurosciences, and nanoscience; (2) duplicate papers; (3) publications (i.e., proceed paper, book chapter, editorial material, early access), because most of them lack keywords to conduct network analysis; (4) papers without access. The authors cross-checked the included papers for data validity and verification. At the end of the review and screening process, 308 articles published by topic search and 89 articles by title search were identified and included in our database.

\subsection{Quantitative Analysis: Bibliometric Analysis of Publications}

The initial citation report, including the data of title, authors, sources title, publication year, total and average citations, and per year citations, were obtained from the WOS. The results of records including publication years, document types, research areas, funding agencies, organizations-enhanced, source titles, countries/regions were analyzed using Excel showing results in Section 3.1.

Bibliometric information was compiled, including cooccurrence of keywords and cocitation analysis to identify highly cited publications and frequently occurred keywords and the clusters by the extent of similarity between documents [59] based on network theory. The network analysis has been demonstrated quite useful regarding concepts with strong interdisciplinary characters $[60,61]$. The keywords acted as the extraction of research concepts, methods, and topics that could reflect the patterns and trends of various NBS fields by applying cooccurrence of keywords based on network analysis [62]. The cocitation analysis of papers could uncover the most popular works and their relations easily. As a result, it was used to develop a comparative study between the six most cited papers with the cocitation frequency to articulate the evolution of NBS and frame better the NBS concept with other related concepts, as well as reflect NBS governance challenges.

Bibliometric analysis was visualized via the software VOSviewer. It is a software tool in a Java programming language that generates visualizations of network data [63]. A minimum of two items of variables (e.g., keywords) could be set as a threshold of interrelations, either cooccurrence or cocitation. The weight attributes depend on the number of links and the total link strength [63]. For each item meeting the threshold, the total strength of the bibliographic coupling links with other items (e.g., cooccurrence links) was calculated. In all cases, the size of nodes indicates the relative importance of the items. The analysis approach of 'LinLog method and modularity clustering technique' was selected to show the network map $[64,65]$ with same-color keywords grouped into one cluster, prior to finding fast-growing topics and areas of collaboration.

\subsection{Thematic Analysis}

Thematic analysis was developed to further investigate NBS in urbanism specifically, as well as urban NBS governance, because it was aroused as one of the most important themes. There were three main steps of thematic analysis. Firstly, we classified all included papers according to their thematic goals, specific themes, study methods, and geographic scope. Secondly, we mapped their inter-relations and discussed the implications. Next, we discussed the papers under each thematic goal.

There were four thematic goals with corresponding research and innovation actions, in the report "Towards an EU research and innovation policy agenda for NBS and ReNaturing cities" published as the first official article for the subsequent NBS research [3]. Each included a paper that mentions corresponding goals were labeled, namely, "Enhancing sustainable urbanization by human well-being (sic) enhancement and urban regeneration; Developing climate mitigation and adaptation; Restoring degraded ecosystem; Improving risk management and resilience". Then we discussed included NBS research under each thematic goal in terms of its evolution, contribution and trend. 
For each paper, besides the corresponding thematic goals (either single or integrated goal) and their specific themes we assigned, such as greening, urban regeneration, wellbeing, governance, water, soil, and air, we have also identified study methods (e.g., review, empirical, conceptual/reflection, and modeling), geographical location of the study and scale of application (e.g., global and Europe). The results of relation flows of NBS studies were shown in a Sankey diagram visually. A four-dimensional typology of NBS publications was created indicating the relationships among study continents, thematic goals, specific themes, and study methods by analyzing the abstract of each paper and the full-text papers.

The specific theme 'NBS governance' was identified with increasingly high interest, but are yet to be fully explored according to results of bibliometric analysis and content analysis in the review process. The inclusion criteria were using 'governance' by topic search within 89 included NBS papers, such as the context about institutionalization, stakeholders, planning, education, policy, and finance. Specifically, these selected papers, including both the general conceptualization and case studies, were summarized (in Appendix A: Tables A2 and A3) and discussed in terms of their thematic goals, specific themes, funding resources, and main contributions.

On the other hand, through this meta-analyses and review, we further discussed the governance approaches (i.e., top-down, bottom-up, hybrid or adaptive). We provided some valuable recommendations to draw the key lessons from case studies to transfer or scale up to foster new NBS strategies. The gaps and trends under this theme were argued, and the recommendations were suggested based on the current pattern of NBS governance.

\section{Results}

The results of analyses were presented below, beginning with the bibliometric analysis of general statistics of publications and network analysis, including the most commonly cooccurring keywords and cocitation relations (Section 3.1), and following in-depth thematic analysis of NBS studies, including thematic goals, specific themes, study methods, and geographic scope (Section 3.2).

\subsection{Bibliometric Analysis}

\subsubsection{General Statistics of Publications}

When we searched keywords of NBS in the topic (English language), there were 541 papers of NBS studies (470 research articles and 71 reviews) in total (until the end of October 2020), accounting for $89 \%$ of the total 611 of all document types. Among these, 308 NBS papers (266 research articles and 42 reviews) in urbanism were identified, accounting for $57 \%$ of total NBS research in general. Specifically, for NBS studies within urbanism context searching by title, there were 89 papers left explicitly focusing on NBS research with 72 articles and 17 reviews. Research articles accounted for the majority of the total number of publications (over 75\%), as opposed to review, proceed paper, book chapter, editorial material, and early access.

The published year of NBS research and review papers started in 2015, and then the number of published works significantly increased since 2016 (when the term 'NBS' was coined). While in 2017-2018 there was a slight fluctuation, the general trends of publication numbers were increasing till the highest number in 2020, indicating a growing interest in this field. The sum of times cited was increasing dramatically in 2018-2019 and 2019-2020, while the annual citation number was the highest in 2017 with 564 for NBS in urbanism (title search) (see Figure 3). 


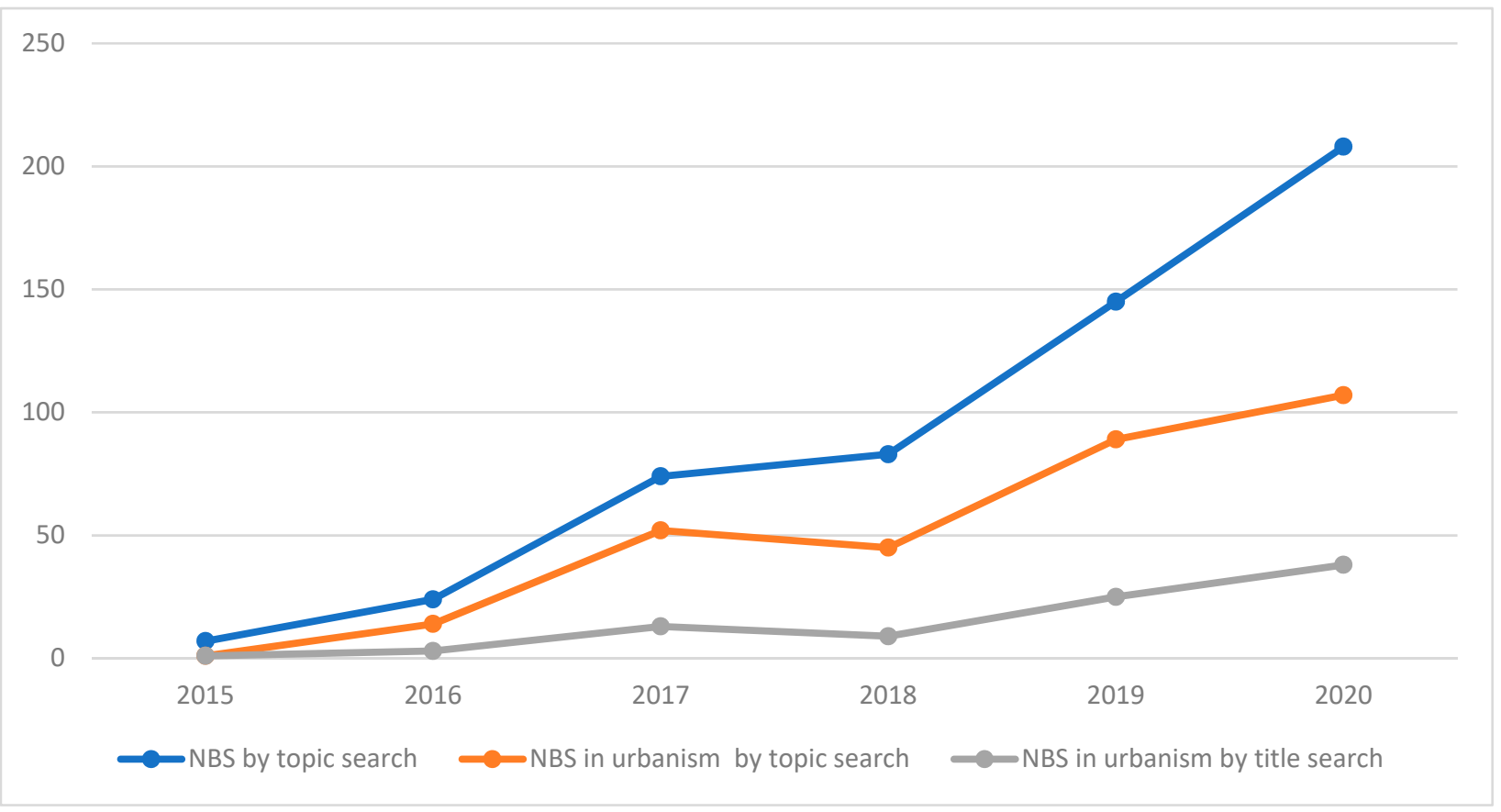

Figure 3. The number of included NBS related publications with the publication year (2015-2020) (Note: The literature data were updated to the end of October, so the figure does not illustrate the complete list of publications for 2020.).

It was notable that most journals were in environmental fields. The top research area was 'Environmental Sciences', with $63 \%, 72 \%$, and $77 \%$, respectively, for NBS related studies in general, NBS in urbanism by topic search and specifically by title search. It was notable that most journals were in environmental fields. The most popular journal published NBS articles were Sustainability, followed by Environmental Research, Science of the Total Environment, and Environmental Science \& Policy, which were included in all three searching results. The reasons could be these journals have a broader scope of NBS studies and the openness to publications in the area of innovative concepts and technologies.

The specific priority research areas on NBS can be divide into land, water, greening, and policy. The land and policy were the most popular within NBS in urbanism by a title search, while the topic search in urbanism focused more on greening and water. Landrelated journals, such as Land, Land Use Policy, and Landscape and Urban Planning, ranked higher specifically in the NBS publications in urbanism than the NBS publications in general (see Table 1).

Table 1. Top eight journals with publication numbers for NBS publications with the calculated percentages.

\begin{tabular}{|c|c|c|c|}
\hline Rank & $\begin{array}{c}\text { Top Journals of NBS Studies in } \\
\text { Urbanism } \\
\text { (Title Search) }\end{array}$ & $\begin{array}{c}\text { Top Journals of NBS Studies in } \\
\text { Urbanism } \\
\text { (Topic Search) }\end{array}$ & $\begin{array}{l}\text { Top Journals of NBS Studies } \\
\text { (Topic Search) }\end{array}$ \\
\hline 1 & Sustainability (15.24\%) & Sustainability $(11.34 \%)$ & Sustainability $(8.68 \%)$ \\
\hline 2 & Environmental Research (12.38\%) & Environmental Research (6.87\%) & Science of the Total Environment (5.65\%) \\
\hline 3 & Science of the Total Environment (4.76\%) & Urban Forestry \& Urban Greening (5.38\%) & Water $(5.65 \%)$ \\
\hline 4 & Environmental Science \& Policy (3.8\%) & Science of the Total Environment (4.78\%) & Environmental Research (4.77\%) \\
\hline 5 & Land use policy (3.81\%) & Environmental Science \& Policy $(2.99 \%)$ & Environmental Science \& Policy (3.36\%) \\
\hline 6 & Land $(2.86 \%)$ & Water $(2.99 \%)$ & Urban Forestry \& Urban Greening (3.36\%) \\
\hline 7 & Urban Forestry \& Urban Greening $(2.86 \%)$ & Landscape and Urban Planning (2.39\%) & Land Degradation \& Development (2.12\%) \\
\hline 8 & Cities $(2.86 \%)$ & Sustainable Cities and Society $(2.39 \%)$ & Ecological Engineering (1.59\%) \\
\hline
\end{tabular}

This may indicate the research on land was one of the key areas of NBS studies in urbanism that urban planning and policy were being important to involve NBS. Using a 
topic search, the research on Urban Forestry \& Urban Greening for NBS studies in urbanism was more popular (5.38\%) compared to NBS studies in general (3.36\%), which indicated the 'greening' was a hot topic in urbanism. Water research was also important with the high-percentage publications using a topic search that might disclose the solutions on water issues using NBS-related approaches.

The most frequent studied countries in NBS research were within the EU, which was not very surprising given that NBS was the major EU-driven policy and the European Commission and European Research Council to provide financial support in various levels (i.e., academic research funding; funding for enhancing NBS projects and practices delivery, funding for the maintenance of the (NBS) measures and structures). In particular, for the Western European countries (e.g., Netherlands, Italy, and Germany) and the United Kingdom (UK), with the largest publications that played a major role in the world's ability to lead NBS research. Italy was also identified as the earliest research case study on NBS, focusing on isolated environmental problems, such as water pollution [66], air quality [21], and soil sealing [14].

For the new EU member states, such as Eastern EU, Poland focused more NBS cases than Czech Republic, Estonia, Romania, Slovenia, and Bulgaria. Outside the EU, there were countries being popular in NBS studies, including China and Australia. Popular NBS case cities identified included Melbourne, Rome, Barcelona, and New York City. In Asia, more cases were in Chinese mega-cities, such as Shanghai and Chongqing, while others were in South Korea, Thailand, India, and Japan.

Geographically, NBS was a popular and widely cited concept among academics of the EU. The rest countries located in Africa, South America, and Asia published only between one to three papers focusing on NBS. The top 10 countries ranked by the number of publications from high to low were the UK (31\% in total and the majority from England with $22 \%$ ), the Netherlands (20\%), Italy (19\%), Germany (16\%), Australia (11\%), Sweden (11\%), China (9\%), Portugal (9\%), Spain (8\%), and the United States (8\%) (Figure 4). They played a dominant role in NBS research and discourse, due to their coauthorships shared with other countries and the number of publications, which can be considered as the 'leading forces'. More links of coauthorship within one country indicated more knowledge and research of NBS could be transferred. Thereby, the EU has a good foundation to share frameworks and cases within the EU member states.

European Commission was the largest organization for NBS research $(15 \%)$, and the European Union was the biggest funding agency for NBS research (18\%), followed by EU Horizon 2020 Research and Innovation Program, Swedish Research Council Formas (Sweden), Federal Ministry of Education Research BMBF (Germany), National Natural Science Foundation of China NSFC (China), and Portuguese Foundation for Science and Technology (Portugal) according to the existing literature search of NBS studies in urbanism. Accordingly, the top organizations-enhanced of NBS research in urbanism were within the EU mostly, especially in Sweden, the Netherlands, Italy, and Germany, such as Swedish University of Agricultural Sciences, Wageningen University research, Humboldt University of Berlin, Universita Degli Studi Di Bari Aldo Moro, Erasmus University Rotterdam, Helmholtz Association, and Technical University of Munich. As a result, funding support and strong organizations-enhanced contributed to higher research productivity in these corresponding countries.

\subsubsection{Network Analysis of Publications: Indicators of Research Integration}

Cooccurrence Analysis of Keywords to Identify Closely Related Concepts, Terms, and Topics

The resulted network graph of the keywords (both author keywords and keywords plus) and connections between those keywords are displayed in Figure 5. The frequency of occurrence of each keyword and the cooccurrence of pairs of keywords were used to indicate the foci of publications. The thickness of the connections represented the frequency of cooccurrence that three keywords occur together, and the size of each sphere (i.e., label and nodes) illustrated the occurrence frequency, and the colors indicated different clusters. 


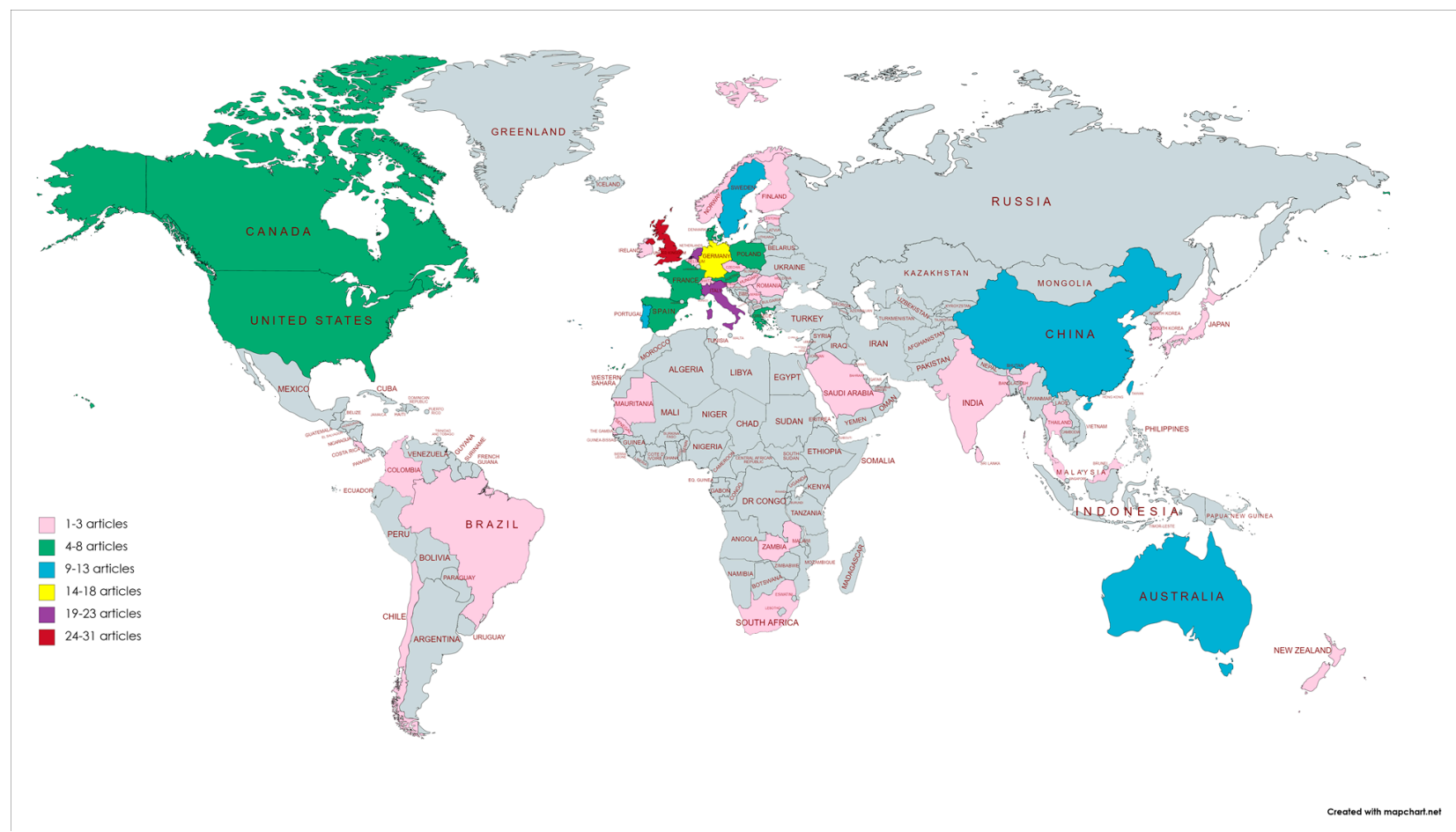

Figure 4. Contribution of global geographic scope to scientific papers (reviews and research articles) on NBS studies in urbanism by title search between 2015-2020 (For interpretation of the references to color in this figure legend. The grey color means no literature within that country identified for this review) (Source: authors).

A total of 80 stemmed and synonyms of keywords were replaced (e.g., nature-based solution was replaced by nature-based solutions). When putting bibliographical data of 89 papers into the VOSviewer, there were 70 keywords of the 638 keywords that met the threshold requirement of minimum three occurrences. For each of 70 keywords, the total strength of the cooccurrence links with other keywords was calculated based on the frequency of times that cooccurred with other keywords.

NBS research in urbanism presented strong relations with terms of ecosystem services (41 occurrences, 66 links, and 265 total link strength) and green infrastructure (with 31 occurrences, 62 links, and 200 total link strength), and climate change (19 occurrences, 47 links, and 109 total link strength). In the second order of importance, NBS was strongly connected with the terms of resilience (14 occurrences, 44 links, and 103 total link strength), and sustainability (15 occurrences, 46 links, and 106 total link strength), and adaptation, including both climate-change adaptation and ecosystem-based adaption. The 'management', 'governance', 'benefits', 'framework', 'challenges', and 'lessons' were the popular keywords identified in NBS publications with the strength of a total link from high to low, respectively.

In addition, it reflected fewer terms involved with social objectives and results (e.g., 'local', 'assess' and 'cohesion'), with 'environmental justice' and 'people' mentioned relatively more frequently. Economic terms linked to cost as expected, with less frequency than environmental and social terms, respectively, showing a stronger tendency of focusing on the environmental and ecological characteristics of NBS.

Keywords among each other with strong association strength were grouped as a cluster, highlighted by the same color in the network. In this context, keywords within a cluster (or community in the broad network analysis) are associated closely with each other and have more common research connections [63]. The relations of two keywords were determined by calculated link strength (presented by the thickness of the connectors rather than proximity of items (as the position in the map was optimized) [63], but the peripheral elements in the map usually have fewer occurrences. 


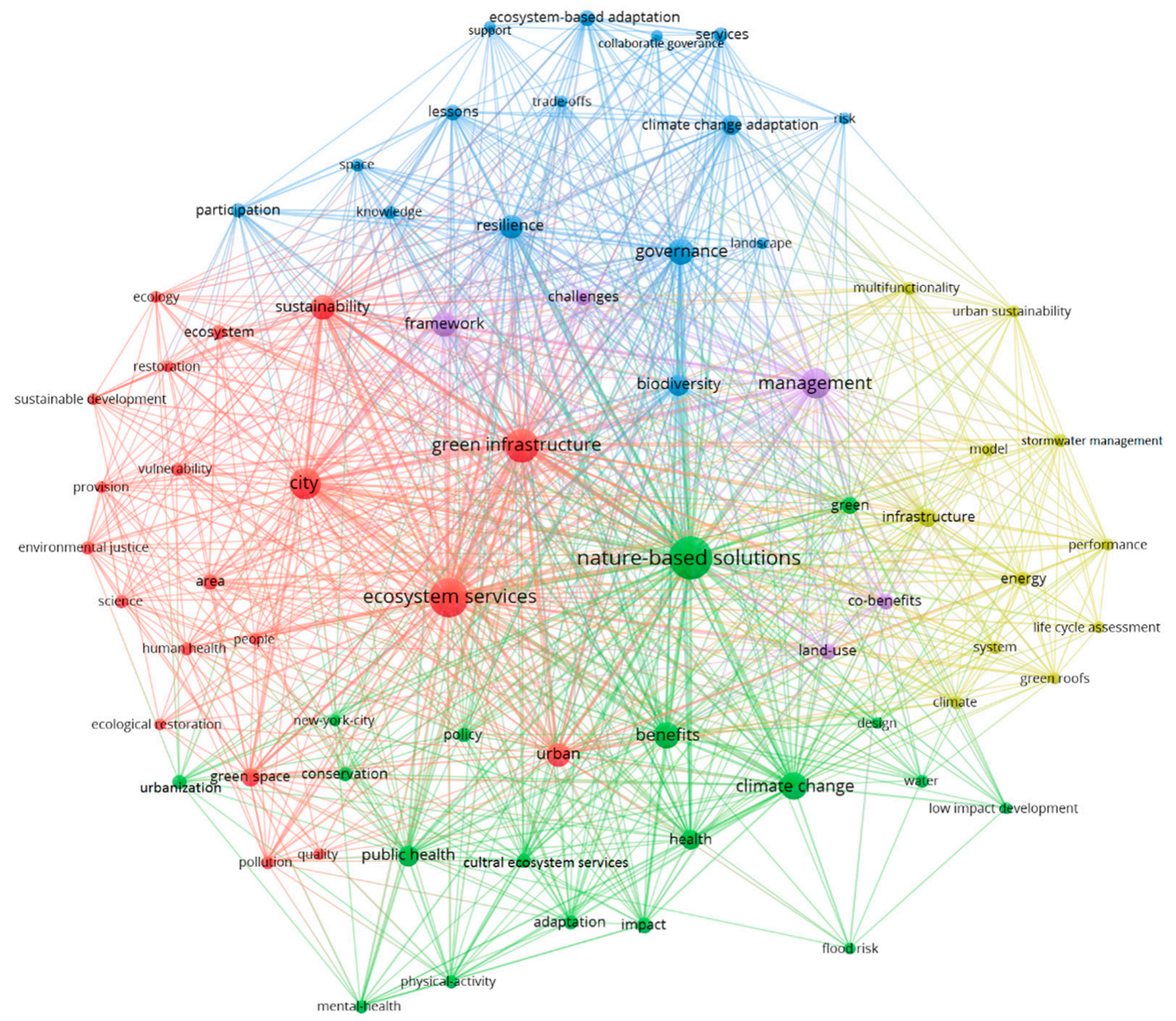

B VOSviewer

Figure 5. Network map of NBS papers in urbanism by VOSviewer using cooccurrence of keyword analysis (Database89 papers between 2015 and 2020).

In fact, we can see that there were 5 clusters in Figure 5. Cluster 1 to 5 accounted for about $29 \%$ (red color), 27\% (green color), 21\% (blue color), 16\% (yellow color) and $7 \%$ (purple color) of all keywords, respectively. Cluster 1 focused on 'ecosystem services' (with the terms 'ecosystem', 'ecology', 'ecological restoration'), and 'green infrastructure' (related to terms of green space). Cluster 2 focused 'benefits' of 'NBS' on 'public heath' and 'water'-related' topic, such as 'low impact development' and 'flood'. Cluster 3 was formed by 'governance'-related studies, including 'collaborative governance', 'knowledge', 'lessons', 'participation', and 'trade-offs'. Cluster 4 addressed the assessment of NBS with the keywords of 'performance', 'life cycle assessment', 'model', and 'system'. Cluster 5 researched the conceptualization of NBS, such as 'challenges', 'cobenefits' , 'management', and 'framework'. It was notable to mention that the link strength between the term of 'governance' and 'NBS' was as same as 'NBS' with 'GI', 'climate change', and 'management', which indicated the importance of governance topic on NBS. 


\section{Cocitation Analysis to Identity Pioneers of NBS Papers}

Cocitation refers to the frequency that two items are simultaneously cited in the literature [67]. Such patterns observed over these years could provide clues to understanding the mechanism of NBS development and insights to the domain of knowledge, which is more reliable than citation-only analysis [68].

There were 5518 cited references, 28 meeting the threshold with 10 as the minimum number of citations of a cited reference (Figure 6). The most cited articles were usually regarded as landmarks because of their ground-breaking contributions [68]. In Table 2, we showed the top six of most cited papers with cocitation frequency. We summarized the content and relations of these papers to facilitate the framing of the NBS concept by illustrating the connections between the NBS concept and other related concepts, also the hotspot of state of the arts in current NBS research and the governance challenges they revealed.

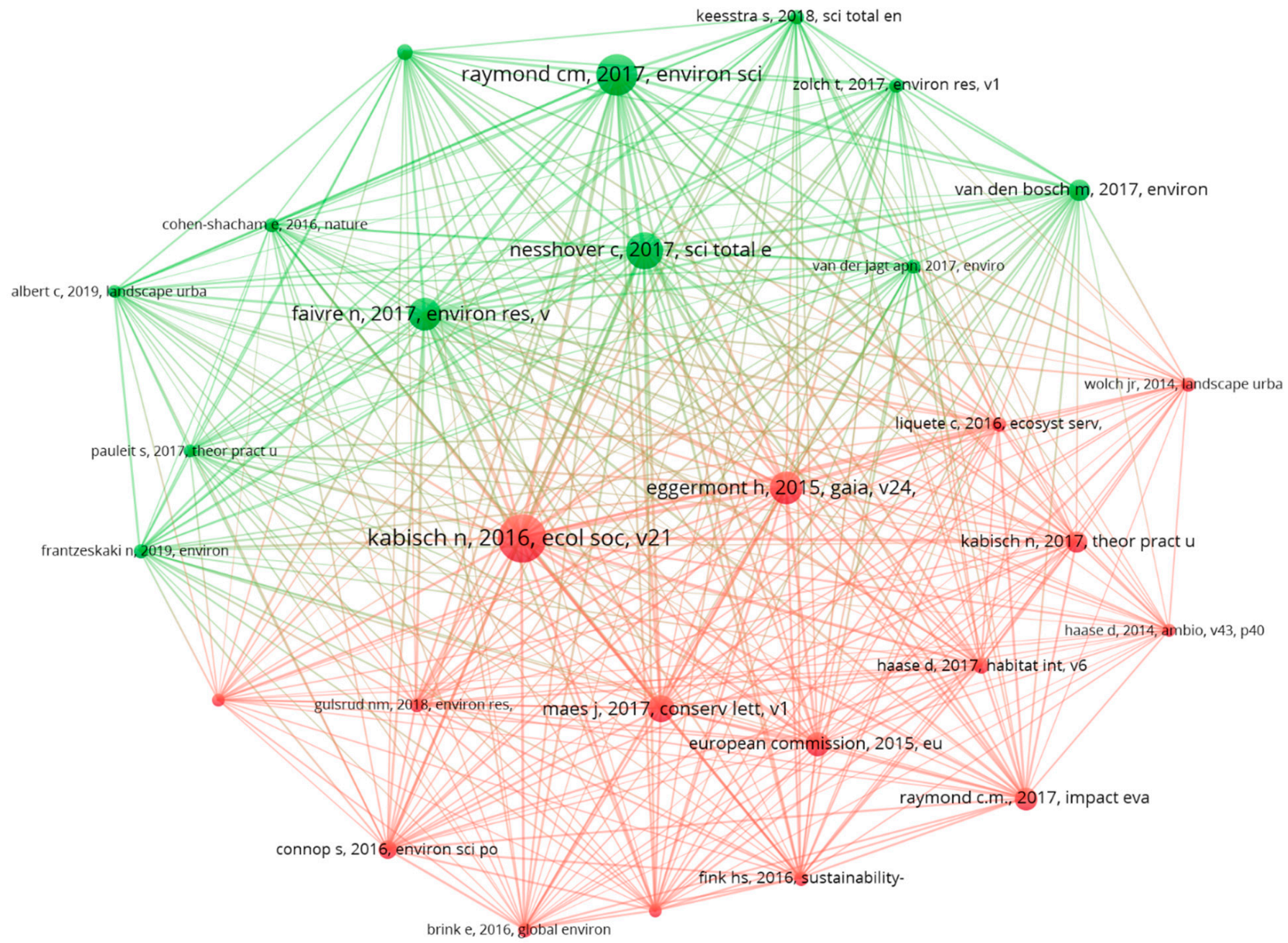

VOSviewer

Figure 6. A visualization of the cocitation network of NBS papers in urbanism with 28 top cocited papers between 2015 and 2020. 
Table 2. Top six most cited papers with the cocitation frequency.

\begin{tabular}{|c|c|c|c|c|c|}
\hline Rank & Title & Source & Cocitations & Topics & $\begin{array}{c}\text { Terms Related to European } \\
\text { Commission's Thematic } \\
\text { Goals }\end{array}$ \\
\hline 1 & $\begin{array}{l}\text { Nature-based solutions to } \\
\text { climate change mitigation and } \\
\text { adaptation in urban areas: } \\
\text { Perspectives on indicators, } \\
\text { knowledge gaps, barriers, and } \\
\text { opportunities for action [69] }\end{array}$ & $\begin{array}{l}\text { Ecology } \\
\text { and Society }\end{array}$ & 40 & $\begin{array}{c}\text { Cobenefits; } \\
\text { Governance; } \\
\text { Indicators, knowledge } \\
\text { gaps, barriers, and } \\
\text { opportunities } \\
\text { for action }\end{array}$ & $\begin{array}{l}\text { Climate-change adaptation, } \\
\text { and mitigation }\end{array}$ \\
\hline 2 & $\begin{array}{l}\text { A framework for assessing } \\
\text { and implementing the } \\
\text { cobenefits of nature-based } \\
\text { solutions in urban areas [70] }\end{array}$ & $\begin{array}{l}\text { Environmental } \\
\text { Science and Policy }\end{array}$ & 34 & $\begin{array}{c}\text { Cobenefits; } \\
\text { Governance; } \\
\text { Framework; } \\
\text { Assessment; Trade-off }\end{array}$ & $\begin{array}{l}\text { Ecosystem services; } \\
\text { Green infrastructure }\end{array}$ \\
\hline 3 & $\begin{array}{c}\text { The science, policy, and } \\
\text { practice of nature-based } \\
\text { solutions: An interdisciplinary } \\
\text { perspective [11] }\end{array}$ & $\begin{array}{l}\text { Science of the } \\
\text { Total Environment }\end{array}$ & 30 & $\begin{array}{l}\text { Science, policy, } \\
\text { and practice }\end{array}$ & Ecosystem services \\
\hline 4 & $\begin{array}{l}\text { Nature-based solutions in the } \\
\text { EU: Innovating with nature to } \\
\text { address social, economic, and } \\
\text { environmental challenges [7] }\end{array}$ & $\begin{array}{l}\text { Environmental } \\
\text { Research }\end{array}$ & 27 & Challenges; Targets & $\begin{array}{l}\text { Climate-change adaptation, } \\
\text { and mitigation; Ecosystem } \\
\text { services; Green } \\
\text { infrastructure; Disaster } \\
\text { risk reduction }\end{array}$ \\
\hline 5 & $\begin{array}{c}\text { Nature-based solutions: New } \\
\text { Influence for Environmental } \\
\text { Management and Research in } \\
\text { Europe [4] }\end{array}$ & $\begin{array}{l}\text { Gaia-Ecological } \\
\text { perspectives for } \\
\text { science and society }\end{array}$ & 27 & Influence; Challenges & $\begin{array}{c}\text { Biodiversity; } \\
\text { Ecosystem services }\end{array}$ \\
\hline 6 & $\begin{array}{l}\text { Nature- based solutions for } \\
\text { Europe's Sustainable } \\
\text { Development [12] }\end{array}$ & $\begin{array}{l}\text { Conservation } \\
\text { Letters }\end{array}$ & 22 & $\begin{array}{l}\text { Policy; Framework; } \\
\text { Criteria; Stages }\end{array}$ & $\begin{array}{c}\text { Biodiversity; } \\
\text { Ecosystem services }\end{array}$ \\
\hline
\end{tabular}

Due to the high cocitations of these papers, they were more influential in the discourse and metaphor for the NBS insights. These six papers all framed NBS in a theoretical level rather than focused on a specific theme or practice. We developed a comparative study to summarize the main targets and the common ground of these papers as follows: (1) Framing NBS several stages from identification, selection, designing, implementation, engaging/communication, transferring/upscaling, to monitoring and evaluation; (2) producing stronger evidence on NBS to address current (and future) social, economic, and environmental challenges (frequently mentioned sustainable urbanization, climate change adaptation, and mitigation, ecosystem restoration, or disaster risk reduction) based on its performance or cobenefit assessment; (3) classifying and justifying NBS as an innovative and cost-effective opportunity from classic/traditional strategies and green-related concepts, including green infrastructure and ecosystem services; (4) reflecting knowledge gaps, potential barriers and opportunities on the implications for science, policy, and practice of NBS with a foci on the European context for its sustainable development.

The cocitations, as well as coauthorship demonstrated the NBS studies, were limited within EU research expert groups as the pioneer researchers. For example, as one of the authors with the highest cocitations, Kabisch was the coauthor with Raymond on the highly-cited NBS framework paper [70]. They identified ten societal challenges in urban areas globally and proposed a seven-stage process for evaluating and employing cobenefits of NBS in policy implementation. The assessment framework of this paper to assess the effectiveness of NBS was developed by EKLIPSE Expert Working Groups funding by the EU and was the most accepted evaluation framework for NBS. The innovation of this framework was that synergies and trade-offs among the challenges reflect a significant 
aspect of the assessment process [36]. This framework [70] as a basis was adopted and refined by some researchers in later studies.

For instance, Frantzeskaki (2019) [71] proposed seven lessons for planning NBS in cities and expanding proof-of-concept and demonstration stages of NBS to organize lessons learned for further studying the issue of sustainable urbanization with NBS. Lafortezza and Sanesi (2019) [72] also adopted this framework [70] as a basis of the DPSIR (Driving force-Pressure-State-Impact-Response) model to explore their impacts on the dynamics of urban areas, in conformity with European Commission standards. Nesshöver et al. (2017) [11] further divided the third step on the designing project of implementing NBS into five dynamic steps, which are ensuring the use of adequate knowledge, concepts and methods, dealing with uncertainty, complexity, ambiguity, and conflicts for trade-offs, guaranteeing the involvement of numerous stakeholders and a wider public, developing a mutual understanding of multiple-functional solutions, evaluating, and monitoring for cross-scale learning. Governance of NBS, such as stakeholder engagement, gradually got more attention for ensuring the success of NBS implementation.

The other three pioneer papers specifically focused on EU context and closely linked with European Commission's four thematic goals [4,7,12], providing insights on multiple benefits of NBS, opportunities, and challenges. Eggermont et al. (2015) [4] proposed a typology of NBS, Which was the first time exploring the NBS in urbanism as a transition type of NBS in different scopes. Faivre et al., (2017) [7] discussed NBS opportunities in wider aspects to address social, economic, and environmental challenges in the EU. They linked NBS by showing examples of approaches that adopt the NBS and its measures across Europe with sustainable development goals (SDGs) in a global policy context. They stressed the EU's research and innovation (R\&I) policy agenda and action to promote NBS by building the evidence base, collecting best-practice examples, creating an NBS community and awareness mainly within EU's Seventh Framework Program (FP7) projects.

Maes and Jacobs [12] in 2017 interestingly highlighted socioeconomic benefits of NBS (i.e., employment opportunities, and low-carbon technology innovations), which were rarely researched compared to environmental benefits. NBS has the potential to provide a transition path with realistic and gradual steps to a sustainable economy as expected by the EU Horizon 2020 vision. The main contribution was proposed criteria to guide and assess the implementation of NBS.

The social-economic impacts and trade-offs between social and ecological developments in cities, such as issues of ecosystem disservices, green/ eco-gentrification were still lacked attention at the early stages of NBS research, though some of them mentioned, for example, NBS is encouraged to explore "win-win" situations, besides trade-offs and uncertainties [4]. It was possible to interpret that this aspect was still in its infancy, and most studies tried to understand the benefits of NBS, in order to push forward it driven by EU-funded NBS projects that four of which are supported by FP7. This justified the goal of our review to synthesize various studies and offer possible future research directions, especially to solve governance challenges with policy, funding, and management on social-economic aspects.

\subsection{Thematic Analysis}

Regarding the thematic analysis, firstly, we analyzed the content of reviewed papers according to four priority areas that EC has identified [3]. Four thematic goals were extracted based on this [3], and then were used to categorize included NBS papers. The results indicated $66 \%$ of NBS publications included over one integrated goal, and $30 \%$ of NBS publications covered all four thematic goals. It was notable that $81 \%$ of included papers mentioned thematic goal 1-'Enhancing Sustainable Urbanization', while 65\% were combined with another three goals.

We analyzed NBS included publications comprehensively and divided them into various narrowed themes, revealing more focus on 'water' (i.e., stormwater, flood, river and lake, sewers, and waterscapes), 'wellbeing' (including public health), 'greening' (including 
the specific topic of GI, green space, green land, green city, urban forest, urban gardens, etc.), 'urban development' (i.e., urban agriculture, urban regeneration, urban resilience, urban sustainability, built environment) (see more details in Appendix A: Table A1). It can be seen that under the NBS context, integrated research has received more attention than isolated topics, such as soil or air (see Figure 7). However, the 'climate change adaptation' by NBS in urbanism has lacked priority [73]. Linkages between NBS and human wellbeing were increasingly understood, but the possibility to create and strengthen social cohesion based on NBS was rather rarely noticed. The least recognized was the impact of NBS on the potential economic development and its governance, especially outside the EU region, which needs more investigation and evidence.

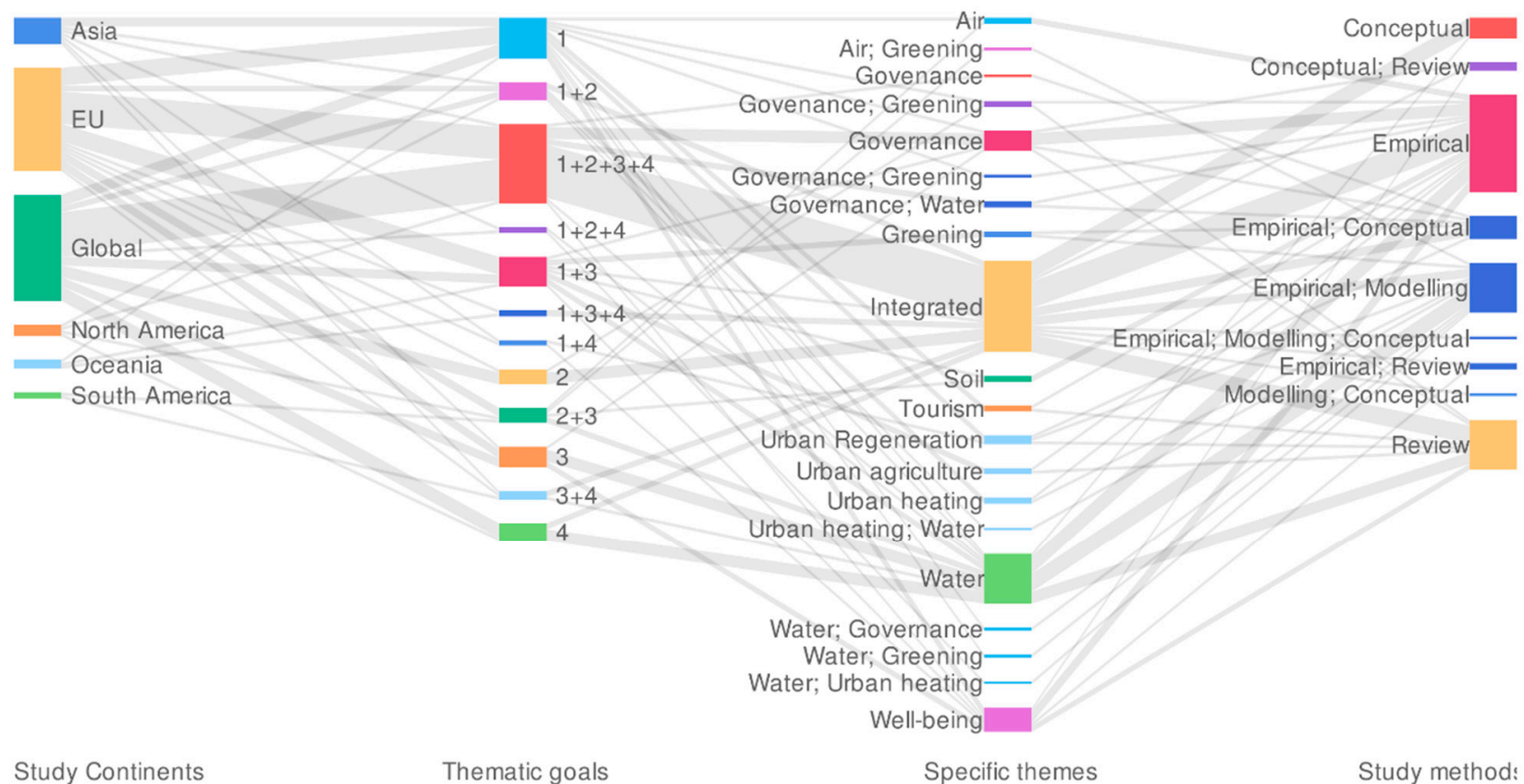

Figure 7. The Sankey diagram indicates the relationship among study continents, thematic goals, specific goals, and study methods. (Note: Thematic goal 1-enhancing sustainable urbanization by urban regeneration and improving wellbeing; thematic goal 2-develop climate mitigation and adaptation; thematic goal 3-restoring degraded ecosystems; thematic goal 4-improving risk management and resilience).

The study methods of included publications that were classified into four types: Review, empirical, conceptual/reflection, and modeling [74]. In this manuscript, we found that the empirical method was the most popular study method $(67 \%$, including integration with other methods). The integration of empirical and modeling was the most frequent among all types of integration (20\%). The empirical method was mainly conducted as case studies using qualitative methods (interviews, workshops, focus groups, and surveys) or experimental approaches. Most papers presented a single case study, with $23 \%$ were cross-case studies, while $42 \%$ of cross-case studies were still within the EU. Modeling (21\%) included economic modeling (e.g., general equilibrium models, regression models, and cost-benefit analysis), evaluation and optimization modeling to understand cobenefits, trade-offs and identify synergies, simulation models (e.g., microclimatic, air dispersion, hydraulic and hydrological models), life cycle assessment, multi-criteria criteria assessment, and participatory analysis. The conceptual method (21\%) reflected frameworks and typologies by identifying and assessing NBS characteristics, principles, indicators, benefits, enablers and barriers, opportunities and risks, pathways, synergies, and trade-offs. The review method accounted for $25 \%$ of all included papers.

To provide insights into the geographic scope of NBS research, the papers were classified into the continents based on the main subject of their work: Europe, Asia, North 
America, South America, Africa, and Oceania. Some global studies covered countries with more than one continent. In some cases, the international level studies applied in the global in general; thus, such cases studies were labeled as 'Global' [51] (see Figure 7). Global and EU-focused research about NBS in urbanism were widely popular. Moreover, integrated research accounted for half of global scope research. The most frequently studied countries were within the EU region, followed by Asia. The case studies on Africa were absent and rare in South America. The research in Oceania and South America both included the thematic goal 3-'restoring degraded ecosystems'. Except for Oceania, all other continents that covered the 'Water' research theme mainly focused on flood risks and water pollution management $-47 \%$ research of this theme was from EU studies.

While popular advocated for, NBS has so far not been implemented systematically, especially in developing countries. Despite their enormous potential, the application of NBS remains highly uneven, marginal, and fragmented within and between countries and cities. We also found that most case studies and authors were actually from the developed countries, especially among European countries. It is anticipated that more applicative studies and researchers from developing countries could contribute to NBS studies. Explicitly we identified the research gaps in developing countries. There was growing research on thematic 1 in terms of urban regeneration (e.g., Asia, especially China [75]). However, research on enhancing sustainable urbanization by human wellbeing was still rare in developing countries. It is crucial to shift the scientific foci of NBS contribution to sustainable urbanization from developed countries to low and middle-income developing countries as they face rapid urbanization pressures, such as inadequate green spaces and GI, population growth, and social stress. The NBS research in developing countries in urbanism regarding thematic goals 2 and 3 were usually integrated with thematic goal 4 for risk reduction and resilience, such as water security in India [76], floods in Brazil [77], integrated disaster risks in Brazil [78], and the Pacific Ocean cities [30].

In addition, the role of NBS as risk solutions was explored in Asia, consisting of urban heat island effects in Thailand [79], and natural disaster vulnerability for urban regeneration in China [75]. However, the research width, by applying NBS as ecological management practices, were limited, and solutions for social challenges (e.g., urban poverty, public health, and business) were even rare due to space availability, data scarcity, immature governance mechanisms, and limited funding in developing nations. Such conflicts between the high demand of NBS and low opportunities to implement NBS in these counties require support from developed countries (e.g., EU) to share more experiences to assistant the uptake of NBS, and cooperate for more research funding opportunities. In contrast, developing nations themselves are encouraged to strive for chances to investigate, learn, corporate, and contribute local knowledge to the field of NBS in return.

There was a growing recognition that the 'governance' was one of the most important themes (accounting for $44 \%$ of all papers) for NBS effective implementation and upscaling to solve a broad range of society challenges [80]. At the same time, there was a growing interest on the political level, such as the latest EU research strategy (see EC 2015 [3]). Research on NBS governance was increasing, especially in recent two years, including the enablers, barriers and strategies for overcoming barriers, (co)benefits, contributions or multi-functionality, principles, steps, and insights for planning, indicators, barriers, knowledge gaps, and opportunities for action.

Hybrid governance as a new type of governance (identified as governed by multiactors) to deliver an upscale urban NBS globally is a key opportunity both in developed and developing countries [81]. The types included market-driven, stakeholder-driven, and citizen-driven. These new governance arrangements (i.e., adaptive governance, hybrid governance, and polycentric governance) have also been proposed as a locally unique approach in implementing the NBS practice, evidently provided from examples on climate change adaptation [82,83], urban biodiversity [84], urban water management [85-87], communal urban gardens [24] in EU region, and urban forestry [88] mostly in Melbourne Australia. 
However, hybrid governance with various choices faced risks of either improvements and deterioration of distributional, recognition, or procedural justice.

Interestingly, we found that was notable for the Asian studies on NBS research currently absent on governance theme and conceptual methods. A total of 35 papers focused on the topic of NBS governance in urbanism, including conceptual studies (e.g., analytical framework to assess cobenefits or policy cycle, transition path, education, NBS thinking, stakeholder engagement, institutionalization) and specific empirical case studies. And we selected 17 papers which were the most typical and influential ones from the included 89 papers to compare and learn lessons on governance approaches (see Appendix A: Tables A2 and A3).

In the following part, we illustrated and discussed NBS research in urbanism under each thematic goal.

Thematic Goal 1: Enhancing Sustainable Urbanization by Human Wellbeing Enhancement and Urban Regeneration

Improving human wellbeing locally, regionally, or globally through the learning and the usage of nature to create sustainable socioecological systems is one of the core themes of NBS. It was also recommended to improve wellbeing in urban areas to promote the goal of sustainable urbanization [3]. Three reviews focusing on wellbeing mainly discussed the evidence, role functions, contributions, and benefits of NBS for public health $[25,26,89]$. These papers indicated a tendency to a positive effect linking specific NBS to different elements of human wellbeing, particularly urban blue-green space and human health, but conclusive evidence was hard to find and quantify. Dick et al. (2019) [89] provided a systematic mapping of the relations between NBS interventions and the related numerous positive and negative human welling-being outcomes across various habitats, in order to identify the potential future environmental evidence challenges for the UK.

Kabisch et al. (2017) [26] focused on specific population groups, van den Bosch and Ode Sang (2017) [59] researched the specific disease with the relations of NBS. Kabisch et al. (2017) [26] provided an overview of the existing evidence specifically on the relationship between the health of population groups of children and the elderly and NBS (urban green and blue spaces) to urbanization-associated challenges. Van den Bosch and Ode Sang (2017) [59] showed strong evidence for an improved effect on heat reduction from green space and then cardiovascular disease (CVD)-related mortality by exposure to NBS (urban natural environments, including blue-green, etc.). The research articles proved the NBS, mainly by the exposure to the green space, could enhance human wellbeing through the cases of depletion of cognitive resources (i.e., less ego depletion) in hot summers [90], improve mental health (recuperation from depression, stress, and anxiety) [91], and minimize the adverse impacts on public health (pollen emissions) [92].

Most studies in this field were published in 2016, and the cases were conducted mostly in developed countries, mainly the western EU and the US, while there is growing research on urban regeneration in developing countries facing rapid urbanization pressures, such as China [75,93]. Urban regeneration can considerably contribute to inclusive urban development, and NBS can act as a catalyst for neighborhood life and promote the creation of new social ties, and simultaneously devote to a healthier urban environment and a more inclusive society [94]. Xiang et al. (2017) [63] demonstrated the contribution and effective measures by using the advanced concept of NBS in Chongqing China to culturally diverse, healthier, and greener regenerative cities (e.g., deprived districts and neglected or abandoned areas), improving living conditions, improved air and water quality, increased GI and biodiversity, enhanced wellbeing, as well as the awareness of re-naturing cities. Furthermore, Xiang et al. [64], lately proposed the concept of inclusive urban regeneration combining NBS with society-based solutions by paying more attention to social aspects.

In summary, achieving sustainable urban development and greening are the more favorable dimensions compared to concerns of previous early years on human adaptation and disaster risk reduction. Evidence assessed almost exclusively from the case studies in developed countries except for a few ones, such as cases in Serbia with numerous acute 
and chronic stressors and accumulated trauma after the general disproportion of urban development and the socioeconomic crisis [91]. The role of NBS within GI in urban development, especially 'resilience and regeneration', is well recognized in developed countries, such as the awareness of cobenefits of GI for public health. Considered the urbanization pressures, including inadequate green spaces and GI, population growth, and social stress, are predicted to take place in low and middle-income developing countries in Asia and Africa, taking the example of China with the enormous need for urban regeneration [75,93], it is necessary to shift the scientific focus of NBS contribution on sustainable urbanization by improving urban regeneration and wellbeing to these regions.

Thematic Goal 2: Developing Climate Mitigation and Adaptation

The discussion of climate change and NBS comes into public more straight and popular after the Paris Agreement was signed in 2016, with the earliest paper related to NBS published by Kabisch et al. and Fink in 2016 [69,95], and increased significantly since 2017. Climate change is frequently mentioned in the NBS studies with over $62 \%$ of publications, and it is one of the closest keywords to the NBS concept according to the keywords cooccurrence analysis.

There were about $55 \%$ of NBS studies mentioned climate change adaptations and mitigation. Reviews, including both climate and NBS in titles, were interpreted from the perspectives of indicators, barriers, opportunities, and knowledge gaps for action in urban areas [69], and connecting science, policy, and communities for evidence-based decisionmaking [82]. NBS has the potential to provide climate adaptation and mitigation measures and simultaneously offer climate-resilient and sustainable planning, especially in urban areas. Plural research outputs have highlighted the valuable role of nature and NBS in addressing climate change in urbanism and the importance of NBS as taking the first step during the integration process between adaptation and mitigation strategies, furthermore implicated its role for broader sustainability $[95,96]$.

NBS is not a panacea for all climate-related urban challenges. The evidence base is still inadequate and needs to be researched considering challenges of the robustness, efficacy, and performance of NBS in distributing numerous benefits to deal with climate mitigation and adaptation in cities. Frantzeskaki et al. (2019) [82] proposed three suggested ways forward, including collaborative research, evaluating schemes and big data, new investment models, and innovative financing mechanisms to implement NBS. Technologybased solutions, cultural-based solutions, and behavior-based solutions should complement the work of NBS. The pioneering article focused on the effectiveness of NBS and contributed to transfer applications and knowledge to the outside the EU [69]. Therefore, an increasingly urgent area is combining multiple solutions and exploration more evidence to address climate change (via adaptations and mitigation); and integrate these aspects by considering socio-environmental justice and cohesion in the governance practice.

Thematic Goal 3: Restoring Degraded Ecosystems

Restoring degraded ecosystems using NBS to improve ecosystems and meet societal challenges is one of the thematic goals of NBS [3]. It was found over half of the NBS publications mentioned restoration and conservation, and almost all publications mentioned keywords related to eco-based (i.e., ecosystem services, ecosystem-based adaptation, eco urbanism, ecological infrastructure, eco-friendly technologies). NBS has fostered novel interdisciplinary knowledge and practices in urban ecosystems [8]. The keyword of 'Ecosystem Services' has a strong link to the NBS concept according to the keywords cooccurrence analysis.

Maes and Jacobs (2017) [12] published one of the pioneer articles on NBS, highlighting the relations with ecosystem services and policies in the EU. This relation with ecosystem services was illustrated by the definition of NBS promoted by several researchers. Nesshöver et al. (2017) [11] compared NBS with related terms, such as GI, ecosystem approach, ecosystem-based adaptation in terms of their definitions, aims, examples, and potential relations to NBS. It reflected NBS on the science, policy, and practice from an 
interdisciplinary perspective since the EC in 2015 framed NBS for transdisciplinary research. Escobedo et al. (2019) [35] further reviewed a series of related metaphors consisting ecosystem services, GI, urban forest with NBS since concepts fostering interdisciplinary knowledge on urban ecosystems have been evolved in the last few decades.

NBS can restore modified ecosystems. In the literature, a large proportion of restoration of ecosystem services within NBS studies discussed the restoration of the water cycle within an urban catchment [97], in line with the recommendations of multifunctional nature-based watershed management and ecosystem restoration by the European Commision (2015) [3]. Water-related NBS concepts are strongly related to the well-known concepts of 'Sustainable Urban Drainage' (SUDS), 'Water Sensitive Urban Design' (WSUD), 'Low Impact Development' (LID), and 'Sponge City Program' (SCP) [98,99].

Some case studies, inspired by NBS to recover and restore lakes [16] and rivers [100] to achieve multiple benefits, take certain measures-mainly include bio-manipulation, small doses of chemicals (to active phosphorus), green linking corridor, and a variety of GI (constructed wetland). The stages of an urban ecosystem developed from conventional, green, sustainable, and restorative to regenerative thinking, to shift from technical systems development to living systems development, and from degenerating to regenerative design to connect natural and human into the landscape pattern in a coevolving relationship [100].

Recently, a consensus has reached that the NBS concept embraces human and ecological benefits beyond fundamental objectives in ecosystem conservation and restoration [36]. In real cases, multiple solutions are conducted, such as the combined grey and blue-green infrastructure. The widespread use of NBS requires a systematic shift from separately relying on several technologies to learning to allow nature to care for them in an integrated way, such as restoring water balance close to the local nature environment and further boost up the natural functions.

Thematic Goal 4: Improving Risk Management and Resilience

Using NBS to improve resilience and risk management could contribute to larger benefits than traditional methods and offer solutions in decreasing various risks of disasters [3]. Over $67 \%$ of NBS publications have mentioned 'resilience' in NBS studies, including resilient landscapes and cities [101,102], resilient human and wellbeing [90], flood and ecosystem resilience [103-105]. It was noticeable a majority of research discussed flood risks and resilience. There were $80 \%$ of NBS publications that referred to 'reduction' of risk factors associated with urbanization, such as air pollution, heat, noise, flood, and food security issues [99,106,107], also for the mental stress [91], urban poverty [108], and economic inequalities [109]. These factors have been reflected in substantial literature proving the role of NBS for risk management and resilient cities and landscapes.

The case studies of NBS for disaster risk reduction have researched flood risks [17,34,84], hydro-metrological risks [104], public health risks [110,111] related to soil pollution. Most disaster risks are related to climate change that focused on urban heat islands or flooding, and the prominent studies for reducing risks of such hazards using BGI (e.g., green space, wetlands, trees, and parks) as adaptation and mitigation strategies [106].

In summary, NBS emerged as innovative solutions with the potential to solve environmental, social, and economic issues that cities are facing today, contributing to protect, manage, and restore natural or modified ecosystems sustainably in urbanism, simultaneously offering multiple benefits, including climate change adaption and mitigation, risk reduction and resilience, and human wellbeing.

\section{Discussions}

This section discussed urban NBS and other related concepts, existing research and its implications, urban NBS governance in the following three sub-sections to answer three research objectives, respectively, with the main findings summarized in Table 3 below. 
Table 3. Results summary from the systematic review in this study.

\begin{tabular}{|c|c|}
\hline Results Types for Research Objectives & Results Details \\
\hline $\begin{array}{l}\text { The number of publications-to answer } \\
\text { research Objective } 2 \text { (current research foci } \\
\text { and trends) }\end{array}$ & $\begin{array}{l}\text { The NBS studies have increased in the } \\
\text { past five years (2015-2020) and were } \\
\text { expected to continue to grow, with 57\% of } \\
\text { NBS related publications have focused on } \\
\text { urbanism, which accounts for } \\
\text { publications in the topic search that were } \\
\text { three times greater than in title search. }\end{array}$ \\
\hline $\begin{array}{c}\text { The top subjects and journals - to answer } \\
\text { research Objective } 2 \text { (current research } \\
\text { disciplinary foci) }\end{array}$ & $\begin{array}{c}\text { Mostly citation flow from the journal of } \\
\text { Environmental Research and } \\
\text { Environmental Science \& Policy. } \\
\text { The most popular two journals that } \\
\text { published NBS articles were } \\
\text { Sustainability and } \\
\text { Environmental Research. } \\
\text { The land-related journals, such as Land, } \\
\text { Land Use Policy, and Landscape and } \\
\text { Urban Planning, ranked higher in the } \\
\text { NBS in urbanism than the total } \\
\text { NBS publications. }\end{array}$ \\
\hline
\end{tabular}

The largest funding continent and organization: European Union and European Commission.

The contributed countries/regions-to answer research Objective 2 (current research countries and funding sources)

The frequent and popular keywords, terms, and themes- to answer research

Objective 1 (the connection between urban NBS and other related concepts); Objective 2 (research foci, specific themes, and trends); Objective 3 (urban NBS governance)
Top 10 countries ranked by the number of publications (from high to low): England, the Netherlands, Germany, Italy,

Australia, Sweden, China, Portugal, Spain, and USA.

Outside the EU, the countries of China, the US, and Australia had greater contributions and applications.

NBS studies presented strong relations with terms of green infrastructure and ecosystem services.

Enhancing Sustainable Urban Development and Greening were the lately favorable dimensions.

The case studies on greening had the most attention, followed by urban development (e.g., urban agriculture and regeneration), wellbeing (mainly public health), and water than isolated soil or air research.

There was a growing number of NBS papers on governance since the last year.
Research Implications

Implied the trend of NBS in urbanism and relevant studies were productive and increasing. The broad content of NBS with other concepts has enriched NBS topic literature.

Implied the trend of NBS publications in multiple and transdisciplinary fields, such as environmental and land-related studies, indicating that governance gradually becomes more important for NBS development.

Implied the trend of NBS publications was dominated in EU member states that funded by the EU Funding Agencies (e.g., ERC).

Case studies and publications were

mainly contributed by developed countries, which indicated more attention should be given to

knowledge/technologies with adaptive NBS to the local context.

Funding for research for NBS

implementation was important in terms of NBS upscaling in practices.

Implied NBS research does not sit on its own as an 'island', but other relevant concepts have been imported.

Implement NBS in practice could take advantage of green infrastructure and ecosystem services in order to achieve broader sustainability goals.

Governance of NBS research could be explored in three ways forward, i.e., hybrid governance, finance incentives, and participatory process with multi-stakeholders integrating local culture and knowledge.

Numerous academic studies on climate change and ecosystem services through systematic review have drawn some assumptions that they are closely linked to the concept of NBS $[4,35,70,112]$. The earliest relevant paper about NBS was found in 2015 . It can be explained by the fact that the term NBS firstly entered the mainstream of scientific literature in the early 21 st century.

This review has found that over $57 \%$ of current NBS literature focused on urbanism and governance themes accounted for $47 \%$ of NBS in urbanism. The field of NBS in general and in urbanism has grown rapidly, particularly with sharp increasing literature since 2018, which was consistent with previous research. For example, according to Hanson 
et al. (2020) [74], around 57\% of NBS publications concern the urban contexts. In the urban context of NBS, parks, private and urban gardens, peri-urban forests within the greening topic were mentioned frequently. NBS can address societal challenges across a wide-ranging of spatial scales and temporal scales; multiple current NBS research articles addressed city scale.

More evidence has emerged globally that the benefits and effectiveness of NBS in addressing environmental, economic, and societal challenges, particularly in highly urbanized areas, from the diverse and inter-related studies. And the thematic analysis of our review also demonstrated the emphasis of NBS studies on greening and sustainable urban development in recent research. A large number of publications were coupling NBS and climate change together through the functions of NBS to improve risk management and resilience in urban areas [56]. More recently, the focus has been shifted to greening in urban areas, such as urban forests than disaster risk reduction.

\subsection{NBS-As an Umbrella and Boundary Concept for Related Terms}

From the analysis of bibliometric analysis, it was found that ecosystem services, GI and climate change has been paid the closest attention to NBS research. Sustainable urbanization, risk management and resilience, ecosystem services, and climate change were key themes related to NBS in the extensive literature since the European Commission set these four thematic goals in 2015. The ecosystem services have been adopted by different authors, disciplines, and regions, and now it is starting to merge and morph into NBS and GI [35].

Some publications integrating provisioning or regulating ecosystem services into GI assessment [108,113], and now considered an essential function of NBS [35], and involved cultural ecosystem services for public health $[91,114]$. We have found that common concerns, such as climate change, sustainability, resilience, conservation, and restoration, are closely connected to NBS and frequently researched using such metaphors (e.g., ecosystem services, GI, and NBS).

As a result, NBS research does not sit on its own as an 'island', but that other relevant concepts have been imported. The advantages of the NBS concept are its integrative and transdisciplinary approach $[11,70,115]$. The results showed the integrated theme of NBS publications accounted for the largest number than isolate topics. NBS might be a good example of a cross-cutting research paradigm as a 'boundary object' that helps break down disciplinary barriers for sustainability.

Although ecosystem services and GI have strong connections with NBS, the NBS literature did not cover them under the overall concept. In practice, what was being implemented and studied were mainly particular components of NBS, such as GI, rather than the umbrella concept of NBS [61]. These terms, metaphors, concepts, or words used were changing in linguistics and discipline knowledge, which were imperative and important for the communication and the transformation of NBS core idea-'Living and using with Natural and Semi-Natural Ecosystems' into practice in cities to strengthen the wellbeing and sustainable urban development.

Concerning the connections between the NBS concept with other related ones, it might still be controversial if NBS is an umbrella concept or a complementary concept in a multi-conceptual framework explaining the connections between humans and nature in socioecological systems. Pauleit et al. (2017) [116] compared four shades of green concepts (i.e., NBS, EbA, GI, and ESS) and concluded that as a powerful umbrella concept. In fact, NBS still relying on further refined definition and deployment of ESS and UGI on the ground systematically in the urban context. Based on this, Tzoulas et al. (2020) [117], who recognized the lacking of consensus in terms of conceptual links between these concepts (either too vague, broad, inconsistent, or missing), further compared NBS with other eight concepts based on six papers $[4,7,11,35,116,118]$ to present the interdependence of human and nature and set a conceptual model of the social-ecological system of NBS in urban environments, which benefited the knowledge transfer at different scales and nations. 
Specifically in the field of landscape planning education. Galan (2020) [119] argued the understanding and application of these concepts differed significantly in academic groups because of their heterogeneous origins. As a result, the synergistic and coordinated usage in this still faced semantic, grammatical, and operational challenges. To create clearer syntaxes between nature concepts to uptake the theory and optimize it in the practice of integrative landscape and urban planning that was suggested.

\subsection{The Implications Among Geographic Scope, Funding Support, and Thematic Goals}

Interestingly, we found that the funding support provided by a variety of organizations through research incentives is, in fact, the driving force that contributes towards the development of numerous subjects within the NBS concept. NBS metaphor has been rapidly adopted by European policymakers and research-funding sources since 2015 [4,70]. Most research findings on NBS governance covered all four EU thematic goals that were applied for global scale by reflecting a framework or inspiring a wide discussion and further upscaling, though they were commonly funded by EU organizations. Changes in funding opportunities, particularly in the EU and the US, and the potential for increased "cite-ability" using important terms were able to interpret the frequent usage of these specific terms [4]. However, to finish projects by using applied funding sources in a certain period may lead to publication growth, but the quality and long-term research and monitoring of NBS projects could be difficult to guarantee.

Another advantage is that the funding opportunities on NBS might attract various umbrella research, such as ecosystem services, green infrastructure, and urban forest. However, they are not specifically focusing on NBS or combined with grey infrastructure as hybrid solutions. We argued by seeing an increasing number of publications on NBS topic, which should give credits to the preferential funding of research projects from the US, Australia, and Countries of the EU (the UK included) [35], and subsequent publications addressed these topics (e.g., European Commission's Horizon 2020 research and innovation program, European Union FP7 program, US National Science Foundation, National Natural Science Foundation of China). A multi-case study transdisciplinary research in 11 European cities was conducted by the Resilient Europe project funded by EU that set up 15 NBS experiments to transfer learnt knowledge on lessons from experiments to urban planning, policy, and governance [82].

European Commission as the key enabler, the proposer, and the primary sponsor for this growth, according to priorities in EU set by Cohesion Policy with 11 thematic objectives supporting growth for the period 2014-2020, Objectives 1-4 were the main priorities for investment by European Regional Development Fund (ERDF).

Among these four objectives, 1 (strengthening research, technological development, and innovation) and 4 (supporting the shift towards a low-carbon economy) are more aligned with the mainstreams of NBS goals, which interpreted and implied that NBS has potential opportunities to promote within the EU. The Objectives 4 and 5 (promoting climate change adaptation, risk prevention, and management), 6 (preserving and protecting the environment and promoting resource efficiency) supported by Cohesion Fund (concerns eastern EU countries) were closely related to NBS, which might support other EU countries with weaker economy to reduce regional disparities. The according to funding mostly are not available in the continents outside the EU.

Other major funding agencies following EU were mainly independent country-level scholarships, such as Swedish Research Council Forms, National Natural Science Foundation of China, Portuguese Foundation for Science and Technology, National Science Foundation NSF (US), National Key Research, and Development Program of China.

In this review, we also found the significant gap for the Global North-South divide regarding scientific productivity and funding for NBS research. Even within the EU region, the western EU and eastern EU have big differences in terms of funding opportunities and research publications. It is evident that NBS case studies outside the western EU lack funding sources, for example, in the countries, such as Brazil [77,78], Costa Rica [120], Sri 
Lanka [121], Poland [16], and South Korea [122]. We found that the EU-funding instruments were mostly available for cities, but the application processes were competitive, requiring additional administrative staff and time and experts. More importantly, cofinancing obstructed numerous cities, especially in developing countries, without mature market mechanisms and investment to afford such projects [112].

China and Australia were the countries with more published documents and author relationships outside the EU. In this review, we have found currently, the NBS field has relatively weak connections between the EU and other continents. Case studies and publications were mainly contributed by developed countries. More attention and support should be given to other parts of regions around the world, especially developing countries, such as those located in Asia, Africa, and South America, as these regions (e.g., Bangladesh and Brazil) are more vulnerable to climate change and increasing urbanizations (i.e., growing populations) and extreme weathers (i.e., urban floods and heatwaves).

In fact, NBS might not be specific enough to accommodate any difference in other countries outside the EU, due to geography, population, social-cultural-political conditions, and there was a sharp learning curve to match such new concept with urban planners and city practicalities. Local place-based knowledge and culture were suggested to cocreate NBS strategies by several research $[4,24,30,81]$. More novel ideas of cities were closely related to NBS, such as 'climate-proof city', 'resilient city', 'green city', 'eco-city' and 'Sponge City'these terms were used in different locations, which could help us to rethink the concepts of urban design and planning. It was not about choosing nature-based or "green" approaches instead of "grey" infrastructure (e.g., canals and pipes). That was a "false dichotomy", according to the UN report. The UN proposing was just adding "green" solutions to the mix more often, an approach "that works with natural systems rather than against them" [123]. By combining existing infrastructure with flexible, decentralized innovations and merging conventional engineering with NBS, infrastructure can be integrated with urban systems for energy, waste, transport, housing, and food supply [9].

Considering the NBS research subjects, most publications were from environmental fields from the broad topics in 'Sustainability' and 'Environmental Sciences' to narrow subject areas, such as green sustainable science technology, ecology, public health, water resources, and forestry. Articles with the NBS concepts indicated that transdisciplinary was increasingly important for NBS studies [74]. Mostly the NBS articles currently were citing and cited in a wide range of disciplines. The keywords and clusters of NBS also came from extensive areas, including "Ecology", "Environment", "Engineering", and "Public Health". Economic terms were less frequently mentioned than environmental and social terms, indicating a strong tendency on the environmental and ecological characteristics of NBS. It was also noted that 'solution', 'approach', 'assessment', 'framework', 'challenges', 'benefits', and 'impacts' were hot research topics, indicating the research foci and directions towards more diverse covering the research categories. These findings unraveled that interand transdisciplinary approaches were increasingly important in providing a common platform for research and promoting innovative and sustainable solutions for urban areas.

\subsection{The Way Forward: Improving the Governance Approaches of NBS in Urbanism}

For the governance mechanisms, there was no evidence of either top-down or bottomup initiatives being more effective than the other. The case studies related to greening especially urban community gardens [24], were notably grass-roots force-led and selfgovernance [55]. The bottom-up of volunteer information applied on NBS in the UK mainly for urban water management [85] highlighted "the most important value of Volunteered Geographic Information may lie in what it can tell about local activities in various geographic locations that go unnoticed by the world's media, and about life at a local level". The initiatives and governance approached largely depended on socio-political context-for example, the Chinese "Sponge Cities Program" via NBS was a more top-down driven and involved multi-stakeholders, however, the competing priorities of stakeholders and their reluctance 
to make trade-offs hindered investment, due to the current political status and hierarchy (traditional) governance structure in China [87].

In fact, there was no single right solution or one-size-fits-all solution to achieve successful governance of NBS. Main enablers involving governance innovation and applying in cases across different planning and social-political-cultural contexts were identified, namely, participatory process (multi-stakeholder engagement), and financial incentives [124]. Common recommendations from the literature of participatory process by multi-stakeholder engagement, such as the collaboration between scientific experts with local communities [81], government institutions with NGOs [125]. Understanding the perspectives of multi-stakeholders to utilize more resources and forms of dialogue to integrate local values and cultures into science-based interventions for the most suitable NBS interventions was important. Usually, the larger the number of services and stakeholder groups were targeted, the lower the ability to maximize the delivery of each services (other than addressing urban stormwater issues) and fulfill the specific needs of all stakeholder groups at the same time, thus trade-off and cost-benefit assessment was further needed [4].

A large number of studies focused on NBS cobenefits and multi-functionality, while there were lacking actions to support citizens to use it. It is gradually realized that transforming experiences or policies from one place to another was difficult, due to the differences of geographical and social-political conditions. Authorities remained doubtable about how they can make NBS being mainstream in their practices. Upscale the implementation of NBS should embed them into the local urban agenda. An assessment of urban policy documents to identify gaps and potentials for NBS inclusion could promote to organize and harmonize different sectors [73]. The environmental characteristics of NBS were well researched by substantial literature, and quantitative methods attracted more attention by decision-makers [61]. The policy should safeguard democratic control and justice, which is socially accepted by diverse stakeholder groups and public. The importance of incorporating policy development into participatory processes that weave together multiple knowledge systems across and within institutions and governance processes was highlighted [70].

Adaptive governance that integrated place-based knowledge and local culture was suggested to cocreate NBS strategies by many researchers for social justice, cohesion, and resilience $[4,24,30,81]$. The application of NBS in the EU may not be directly replicable for ocean-focused regions, such as cities located in the Pacific Rim, with a considerably important and relevant traditional knowledge and emerging NBS experience [30]. The NBS studies in different regions faced various types of challenges. For example, Southern Europe was at the forefront of climate change [37], and their solutions combined with local knowledge can inform global understanding to address coupling risks of urbanization and climate change, but showed less attention among the South-Eastern and Eastern EU member states [37].

Inadequate financial resources also considerably hindered the NBS implementation. Previous studies identified the availability and limited funding as a barrier for NBS, as well as space availability and data scarcity in the rapidly urbanizing setups in developing nations [120]. Similarly, the ecosystem-based solutions within NBS indicated the lessons that policy mainstreaming was inadequate: Funding instruments should be integrated with the policy framework to facilitate the implementation and adaption. Multiple funding sources across policy streams should demonstrate cobenefits, therefore, ensure stakeholders support [22].

Whilst, the extent of multiple benefits of NBS (such as urban forests) was largely dependent on the availability of funding, urban forest management objectives, the primary delivery agents of urban forests, and the understanding of ecosystem service concepts within local governments [126]. For nature-based stormwater treatment systems (e.g., constructed wetlands, ponds/basins, and rain gardens), the cases studies, such as Water Sensitive Urban Design (WSUD) in Melbourne, Australia [127], and Sponge cities in China, revealed a similar issue that the budgeted funding, in reality, was not reliable enough 
to predict systems' usage, and thus, policymakers prefer to plan expenditures based on installation costs. And the willingness to pay from the public was not as high as expected to cover the long-term costs, including maintenance fees [128].

Furthermore, potential funders, investors, and decision-makers were unconfident that NBS initiatives they support were effective and scalable, and considered potential externalities. In order to fill the gap, IUCN (2020) establish a governance structure of NBS global standard to analyze and evaluate NBS projects. It depicted that the international standard committee (oversight and safeguarding, revision of standard) need the input and feedback loop from the science and knowledge committee (scientific oversight of standard research priorities and evidence base for standard revisions), national/regional hubs (technical expertise, capacity-building, standard adaptation and assurance, user and learning community), and user group (community of practice). Therefore, to upscale the implementation of NBS and improve its effectiveness, thus, to increases NBS investment confidence, interested stakeholders were encouraged to pilot the global standard in current and future applications, and engage with such governance structure.

\section{Conclusions}

This paper explored how current studies of NBS were researched and interpreted in scientific peer-reviewed publications and different thematic fields, how NBS were implemented in practices connecting with related concepts. This paper contributed by identifying future research gaps and broadening the understanding of NBS works to sustainable urban development.

In this study, we found a large number of environmental issues, such as climate change adaptation and mitigation, disaster risk reduction and resilience management, ecosystem conservation and restoration, and sustainable urbanization. These issues have been gradually embedded into science and policy agendas via the instrument of NBS; for example, in a specific way of GI in urban context-though it has still not reached a consensus on the conceptual links between NBS and other concepts in the social-ecological system.

With the increasing studies of NBS, more sound evidence of the NBS multiple functions have added more weights to include NBS in urban planning strategies, while such practices still remained relatively niche, especially in developing countries, because of persistent myths about their feasibility and funding limitation. We demonstrated some vibrant pathways to inform researchers and decision-makers that on the future research foci, gaps, and pathways via our detailed meta-analysis from four major research themes, specific themes, and the governance discussion in this review.

In fact, the EU has taken the opportunity to strengthen its leading global role in urban sustainability with extensive case studies, social practices, research, and policy. We concluded by highlighting the applications and knowledge transfer potential of NBS to other regions of the world especially developing nations, as well as adapting for challenges in terms of governance, finance, and justice in a socioecological system when implementing NBS, which provided some 'Global Best Practice/Champion of Practice' aspects already and started influencing non-EU countries, such as China, as stated in this paper.

Although there was no 'one-size-fits-all' solution to achieve successful governance of NBS, main gaps involving governance and applying in cases across different planning and social-political-cultural contexts were identified, with corresponding recommendations, namely, adaptive governance, participatory process (multi-stakeholder engagement), and financial incentives.

The recent NBS paradigm was constructed most recently as a leeway from the previous knowledge, decisively entering into a domain with more transdisciplinary knowledgeexchange. This was in line with offering more pragmatic solutions rather than unification [35]. In this way, future literature mining could be explored with more detailed and comprehensive searching strategies and analysis tools (e.g., CiteSpace and Gephi for visual analysis as each software have drawbacks and advantages, and more thematic and comparative analysis for evaluation in details), for example, the application of specific techniques 
of NBS (e.g., different types of GI) in different nations, disciplines, and dimensions could be explored in-depth, as well as their relations and knowledge transfer.

Furthermore, selected thematic fields (as per European Commission) were mainly based on EU viewpoints at the early stage of NBS (proposed in 2015) and focused more on environmental issues. With the dynamic development of NBS in both theory and practice, the perspectives and frames aroused in developing countries are encouraged to be investigated and combined with EU pioneer insights in future research to maximize the knowledge transfer and experience sharing.

After this systematic review, we would like to offer some key recommendations for future research and policy insights as follow:

(1) The linkages of NBS and GI as its solutions in practice, and how they link to four types of ecosystem services; the application of NBS with other methods (i.e., green-grey measures) for maximized benefits in the real cases of urban planning and management, gradually shifting to more NBS strategies in urban agenda. That could be contributed from multiple stakeholders through a participatory process of learning-by-doing experiences, linking scientific research and policy with local techniques, knowledge, and culture;

(2) The assessment and research at a different scale from micro-scale to macro-scale and crossing different habitats to provide evidence that is not limited to cities and urban context; the wide-scale, upscale, and refinement of NBS linking air-soil-water metrics and various institutions for more rational decision-making;

(3) The adjustment of the governance to be more adaptive of local context and promote the integration of NBS into urban planning agenda; incorporation both environmental aspects with social justice goals and financial opportunities; highlighting best practices and promoting NBS to bridge communications and strengthen the evidence of multiple benefits of NBS, therefore allocate adequate budget and explore innovative financial mechanisms for the implementation, monitoring, and maintenance of NBS in a long-term legacy;

(4) The evaluation of NBS from comprehensive and transdisciplinary aspects, considering the cost-effectiveness, cost-benefits, multiple criteria analysis, life-cycle assessment, and socio-environmental justice; the development of multi-lateral dialogues and collaboration mechanisms for proactive investment, multiple assessments, selfassessment, and knowledge transfer in planning procedures between policy, practice, and science.

Author Contributions: Conceptualization, L.L., A.C., F.K.S.C. and C.D.I.; methodology, L.L.; software, L.L.; validation, L.L., A.C., F.K.S.C. and C.D.I.; formal analysis, L.L.; investigation, L.L., A.C., F.K.S.C. and C.D.I.; resources, L.L.; data curation, L.L.; writing-original draft preparation, L.L.; writing-review and editing, A.C., F.K.S.C. and C.D.I.; visualization, L.L.; supervision, A.C., F.K.S.C. and C.D.I.; project administration, A.C.; funding acquisition, A.C. and F.K.S.C. All authors have read and agreed to the published version of the manuscript.

Funding: This research was funded by the National Natural Science Foundation of China (NSFC), grant number 71950410760", which also funded the APC. The corresponding author also thanks The Ministry of Education, Culture, Sports, Science and Technology (MEXT) and Hiroshima University in Japan. We also acknowledge NSFC for grant number 41850410497, as well as the National Key R\&D Program of China, grant number 2019YFC1510400. We sincerely thanks the Faculty of Science and Engineering (FoSE), at the University of Nottingham Ningbo China for the provision of a Postgraduate Research Scholarship for the Ph.D. researcher working on the project.

Institutional Review Board Statement: Not Applicable.

Informed Consent Statement: Not Applicable.

Data Availability Statement: Not Applicable.

Conflicts of Interest: The authors declare no conflict of interest. 


\section{Appendix A}

Table A1. The number and details of identified specific themes of NBS studies in urbanism.

\begin{tabular}{ccc}
\hline Identified Characteristics of Studies & Number of Identified Case Studies & Details within Study Themes \\
\hline Climate change & 44 & $\begin{array}{c}\text { Climate adaptation } \\
\text { (measures/strategy/governance); Climate } \\
\text { change mitigation and adaptation; Climate } \\
\text { action; Climate resilience strategies; Climate } \\
\text { Change Risk Reduction; Climate change; Future } \\
\text { climate conditions. }\end{array}$ \\
\hline
\end{tabular}

Urban agriculture; Urban regeneration; Urban resilience; Urban sustainability; Architectural and urban design; Urban living labs; Urban landscapes, Urban policy; Urban heat island effects; Sustainable development goals; Urban tourisms; Built environment.

Green Infrastructure (edible GI/green roofs/urban wetlands); Blue and green

Greening

77

Wellbeing

Governance

35

Water

71

Air 12 infrastructure; Urban ecological infrastructure; Green technologies; Greening cities; Green land use; Urban forest (riparian); Urban gardens; Urban trees; Urban green spaces; Urban parks; Urban meadows; Green facades (living walls).

Public health; Human resilience and wellbeing; Mental health; Healthy communities.

Collaborative governance; Hybrid governance; Adaptive governance; Polycentric governance; Volunteer information; Partnership among stakeholders; Knowledge sharing mechanisms and technologies; Economic instrument; Plans, acts, and legislations; Education and training.

Stormwater treatment systems; Wastewater treatment/water pollution control; Water quality changes; Water security; Water resources; Water environment; Waterscapes; Urban water problems; Urban rivers/lakes/groundwater;

Hydrological/meteorological resilience;

Flood/stormwater/surface runoff management/regulation/reduction; Coastal protec-

tion/resilience/adaptation/regeneration/artificial structures; Sustainable water management.

Air purification; Air quality improvement; Air/aerosol pollution/contaminants; reduction of increasing ozone level; Carbon dioxide emissions; Carbon flux dynamics; Removal of PM11; NO2;

Soil quality; Contaminated land remediation and brownfield redevelopment; Mitigate soil 
Table A2. The summary of six papers on NBS governance in general (without case studies).

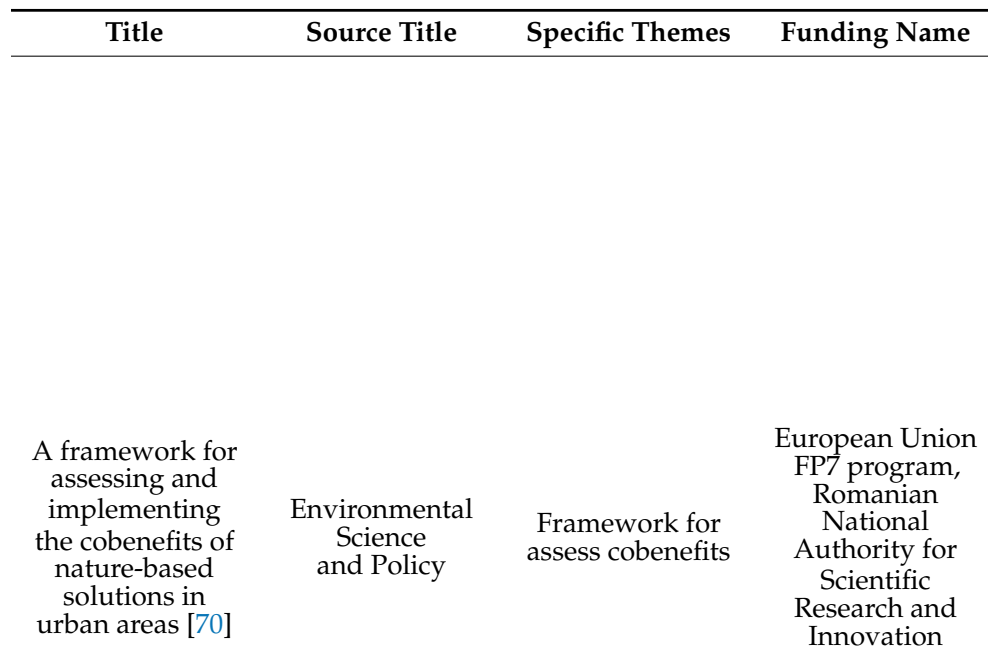

(1) Proposed a framework for assessing NBS cobenefits across various challenge areas considering relevant indicators and methods; (2) translated the framework from theoretical support to practical importance by presenting a seven-stage process to guide thinking and identify the multiple values of NBS.
Recommendation

(1) The selection and assessment of NBS-related actions require the participation of a wide range of stakeholders, multi-disciplinary teams, and policy and decision-makers; (2)

Future research needs to invest in cobenefit analyses across scales and coevaluation across multiple challenge areas, and across multiple stages of NBS implementation; (3) consider how

opportunities or threats

(among others) are

likely to constrain or

promote different policy options in urban areas;

(4) consider how such assessments are embedded within a holistic process of option selection, NBS

design implementation, monitoring, and evaluation and upscaling.

(1) Education of existing and future infrastructure

professionals; (2) reform

of institutions and their

cultures; (3) communityempowered

placemaking combined with 'ecosystem

literacy'; and (4) a new approach to public and private sector procurement.

NBT builds on the three dimensions of ecology, community

participation aspects, and the governance context, as well as the interlinkages between the three dimensions.

Educational programs for engineers must include high-level cognitive skills related to these competencies because NBS projects require not only

traditional engineering skills, but also complementary skills related to the competencies. 
Table A2. Cont.

Source Title Specific Themes

Funding Name

(a) Analysis of perceptions,

Stakeholders' Engagement on Nature-Based

Solutions: A

Systematic

Literature

Review [37]
Sustainability Stakeholders engagement
Foundation for Science and Technology (FCT), Portugal preferences, and perspectives of citizens and stakeholders; (b) analysis of the participation process, including challenges and opportunities, motivations, methods, and frameworks, and collaborative governance.
Recommendation

The lack of research (1) applied to countries of southern Europe and the almost nonexistent

research applied to

Africa and South

America, which

preclude the

establishment of a

comprehensive

theoretical and

empirical knowledge of

the participation

processes during their

several steps from the

conceptualization to the

implementation and

management of NBS; (2)

economic benefits and

those raising the quality

of life in cities; (3) the

risks perceived by citizens and

stakeholders due their involvement in NBS,

and how NBS are perceived as

contributing to reduce social injustice; (4) the possibility of using the participatory process in

NBS to prevent conflicts between the various interests involved; (5) interconnect the

theoretical conceptions and the practice of participation processes

in NBS, in order to

adjust the citizens' and stakeholders' expected

difficulties and the ones faced in

reality-mitigating, in accordance, eventual frustrations of those

involved and promoting the maintenance of collaboration during the life cycle of the implemented NBS, as well as in future projects; and (6) evaluate the contribution of participatory processes for the quality of decisions, the building of public trust in the decision-making process, and for the success of implemented social-learning 
Table A2. Cont.

\begin{tabular}{|c|c|c|c|c|c|}
\hline Title & Source Title & Specific Themes & \multicolumn{2}{|c|}{ Contribution } & Recommendation \\
\hline $\begin{array}{c}\text { The Institutional- } \\
\text { ization of } \\
\text { Nature-Based } \\
\text { Solutions-A } \\
\text { Discourse } \\
\text { Analysis of } \\
\text { Emergent } \\
\text { Literature [61] }\end{array}$ & Resources-Basel & Institutionalization & $\begin{array}{l}\text { European } \\
\text { Commission's } \\
\text { Horizon } 2020 \\
\text { research and } \\
\text { innovation } \\
\text { program }\end{array}$ & $\begin{array}{l}\text { Assessed how } \\
\text { the scientific } \\
\text { literature } \\
\text { regarding NBS is } \\
\text { addressing } \\
\text { institutional } \\
\text { aspect and how } \\
\text { it is constructing } \\
\text { the NBS } \\
\text { narrative by (1) a } \\
\text { quantitative } \\
\text { analysis of the } \\
\text { discourse, } \\
\text { considering } \\
\text { actor, } \\
\text { institutional, } \\
\text { planning, policy, } \\
\text { and regulation; } \\
\text { (2) adopted a } \\
\text { qualitative } \\
\text { analysis } \\
\text { considering both } \\
\text { the most cited } \\
\text { articles and of } \\
\text { articles } \\
\text { highlighted in } \\
\text { the previous } \\
\text { stage }\end{array}$ & $\begin{array}{l}\text { (1) Lack research to } \\
\text { point out the } \\
\text { importance of } \\
\text { institutions and } \\
\text { administrative units to } \\
\text { promote efficient } \\
\text { incorporation of NBS; } \\
\text { (2) the next years are } \\
\text { decisive for the success } \\
\text { of NBS, not only as a } \\
\text { concept, but also as a } \\
\text { "wind of change" in the } \\
\text { form of governance; (3) } \\
\text { adapt institutions and } \\
\text { forms of governance in } \\
\text { order to foster the } \\
\text { incorporation of NBS } \\
\text { into urban planning } \\
\text { regardless quantitative } \\
\text { approaches solidify the } \\
\text { interest of NBS for } \\
\text { technicians and } \\
\text { decision-makers. }\end{array}$ \\
\hline
\end{tabular}

Table A3. The summary of 11 selected representative case studies on NBS governance.

\begin{tabular}{|c|c|c|c|c|c|c|c|}
\hline Title & Thematic Goals & Specific Themes & $\begin{array}{c}\text { Study } \\
\text { Continents and } \\
\text { Case Study }\end{array}$ & Funding Name & Source Title & Contribution & Recommendation \\
\hline $\begin{array}{c}\text { A Methodology } \\
\text { of Policy } \\
\text { Assessment at } \\
\text { the Municipal } \\
\text { Level: Costa } \\
\text { Rica's Readiness } \\
\text { for the } \\
\text { Implementation } \\
\text { of Nature-Based- } \\
\text { Solutions for } \\
\text { Urban } \\
\text { Stormwater } \\
\text { Management } \\
\text { [86] }\end{array}$ & $1+2$ & $\begin{array}{c}\text { Urban } \\
\text { Stormwater } \\
\text { Management }\end{array}$ & $\begin{array}{c}\text { Central } \\
\text { America-Costa } \\
\text { Rica }\end{array}$ & $\begin{array}{c}\text { Germany } \\
\text { (Federal Ministry } \\
\text { of Education and } \\
\text { Research in } \\
\text { Germany) }\end{array}$ & Sustainability & $\begin{array}{l}\text { The ability of } \\
\text { experimentation } \\
\text { to prompt } \\
\text { scalability and } \\
\text { transferability } \\
\text { of results. }\end{array}$ & $\begin{array}{l}\text { Suggests the } \\
\text { inter-municipal } \\
\text { cross- } \\
\text { institutional } \\
\text { collaboration } \\
\text { and the } \\
\text { recognition of } \\
\text { external trigger } \\
\text { events } \\
\text { incentivize a } \\
\text { sustainable } \\
\text { urban transition. }\end{array}$ \\
\hline $\begin{array}{l}\text { A Methodology } \\
\text { of Policy } \\
\text { Assessment at } \\
\text { the Municipal } \\
\text { Level: Costa } \\
\text { Rica's Readiness } \\
\text { for the } \\
\text { Implementation } \\
\text { of Nature-Based- } \\
\text { Solutions for } \\
\text { Urban } \\
\text { Stormwater } \\
\text { Management } \\
\text { [86] }\end{array}$ & $1+2$ & $\begin{array}{c}\text { Urban } \\
\text { Stormwater } \\
\text { Management }\end{array}$ & $\begin{array}{c}\text { Central } \\
\text { America-Costa } \\
\text { Rica }\end{array}$ & $\begin{array}{c}\text { Germany } \\
\text { (Federal Ministry } \\
\text { of Education and } \\
\text { Research in } \\
\text { Germany) }\end{array}$ & Sustainability & $\begin{array}{l}\text { The ability of } \\
\text { experimentation } \\
\text { to prompt } \\
\text { scalability and } \\
\text { transferability of } \\
\text { results. }\end{array}$ & $\begin{array}{l}\text { Suggests the } \\
\text { inter-municipal } \\
\text { cross- } \\
\text { institutional } \\
\text { collaboration } \\
\text { and the } \\
\text { recognition of } \\
\text { external trigger } \\
\text { events } \\
\text { incentivize a } \\
\text { sustainable } \\
\text { urban transition. }\end{array}$ \\
\hline
\end{tabular}


Table A3. Cont.

\begin{tabular}{|c|c|c|c|c|c|c|c|}
\hline Title & Thematic Goals & Specific Themes & $\begin{array}{c}\text { Study } \\
\text { Continents and } \\
\text { Case Study }\end{array}$ & Funding Name & Source Title & Contribution & Recommendation \\
\hline $\begin{array}{c}\text { Beyond } \\
\text { participation: } \\
\text { when citizen } \\
\text { engagement } \\
\text { leads to } \\
\text { undesirable } \\
\text { outcomes for } \\
\text { nature-based } \\
\text { solutions and } \\
\text { climate change } \\
\text { adaptation [132] }\end{array}$ & 2 & $\begin{array}{l}\text { Climate change } \\
\text { adaptation }\end{array}$ & $\begin{array}{l}\text { EU-5 cities in } \\
\text { Sweden }\end{array}$ & $\begin{array}{l}\text { Sweden (Lund } \\
\text { University, } \\
\text { Swedish } \\
\text { Research Council } \\
\text { FORMAS, Mistra } \\
\text { Urban Futures) }\end{array}$ & Climatic Change & $\begin{array}{c}\text { Examined } \\
\text { whether (or not) } \\
\text { current forms } \\
\text { and conditions } \\
\text { of citizen } \\
\text { involvement } \\
\text { help to create a } \\
\text { platform to } \\
\text { support } \\
\text { nature-based } \\
\text { solutions and } \\
\text { ensure a } \\
\text { transformative } \\
\text { adaptation } \\
\text { process. The } \\
\text { results show that } \\
\text { under current } \\
\text { conditions, } \\
\text { citizen } \\
\text { engagement } \\
\text { often hampers } \\
\text { sustainable } \\
\text { outcomes. }\end{array}$ & $\begin{array}{l}\text { Unclear that } \\
\text { personal spheres } \\
\text { of } \\
\text { transformation } \\
\text { toward } \\
\text { sustainability } \\
\text { regarding } \\
\text { citizens, civil } \\
\text { servants, and } \\
\text { decision-makers. } \\
\text { Key constraints } \\
\text { are power } \\
\text { structures and } \\
\text { the lack of } \\
\text { cognitive/ } \\
\text { emotional and } \\
\text { relational } \\
\text { capacities } \\
\text { required for } \\
\text { improved } \\
\text { democratic } \\
\text { governance. If } \\
\text { we are to tap into } \\
\text { the potential of } \\
\text { NBS to increase } \\
\text { climate } \\
\text { adaptation } \\
\text { governance, we } \\
\text { need targeted } \\
\text { financial and } \\
\text { human } \\
\text { resources, and } \\
\text { greater capacity } \\
\text { to overcome } \\
\text { current } \\
\text { constraints and } \\
\text { support all levels } \\
\text { and phases of } \\
\text { mainstreaming, } \\
\text { notably } \\
\text { planning, } \\
\text { implementation, } \\
\text { monitoring, and } \\
\text { learning. }\end{array}$ \\
\hline $\begin{array}{l}\text { Cultivating } \\
\text { nature-based } \\
\text { solutions: The } \\
\text { governance of } \\
\text { communal urban } \\
\text { gardens in the } \\
\text { European Union } \\
\text { [24] }\end{array}$ & 1 & $\begin{array}{l}\text { Communal } \\
\text { urban gardens }\end{array}$ & $\begin{array}{c}\text { EU-6 CUG cases } \\
\text { in EU cities (i.e., } \\
\text { Solvenia, UK, } \\
\text { Sweden, } \\
\text { Portugal, } \\
\text { Hungary) }\end{array}$ & $\begin{array}{l}\text { European Union } \\
\text { FP7 program }\end{array}$ & $\begin{array}{l}\text { Environmental } \\
\text { Research }\end{array}$ & $\begin{array}{l}\text { Identify a broad } \\
\text { range of } \\
\text { governance } \\
\text { aspects, } \\
\text { including } \\
\text { partnerships and } \\
\text { participation, } \\
\text { predicting the } \\
\text { success of CUG } \\
\text { initiatives in } \\
\text { delivering social } \\
\text { resilience; } \\
\text { particularly } \\
\text { identifying } \\
\text { innovative } \\
\text { governance } \\
\text { arrangements } \\
\text { effective in } \\
\text { promoting the } \\
\text { uptake of CUG } \\
\text { as NBS. }\end{array}$ & $\begin{array}{l}\text { For CUG to } \\
\text { achieve } \\
\text { community } \\
\text { buy-in and to } \\
\text { flourish, } \\
\text { ultimately we } \\
\text { need an } \\
\text { approach that } \\
\text { enables local } \\
\text { people to } \\
\text { discover, } \\
\text { nourish, adapt } \\
\text { and cocreate } \\
\text { their own } \\
\text { culture. }\end{array}$ \\
\hline
\end{tabular}


Table A3. Cont.

\begin{tabular}{|c|c|c|c|c|c|c|c|}
\hline Title & Thematic Goals & Specific Themes & $\begin{array}{c}\text { Study } \\
\text { Continents and } \\
\text { Case Study }\end{array}$ & Funding Name & Source Title & Contribution & Recommendation \\
\hline $\begin{array}{l}\text { Examining the } \\
\text { policy needs for } \\
\text { implementing } \\
\text { nature-based } \\
\text { solutions in } \\
\text { cities: Findings } \\
\text { from city-wide } \\
\text { transdisciplinary } \\
\text { experiences in } \\
\text { Glasgow (UK), } \\
\text { Genk (Belgium) } \\
\text { and Poznan } \\
\text { (Poland) [133] }\end{array}$ & $1+2+3+4$ & Integrated & $\begin{array}{l}\text { EU_Glasgow } \\
\text { (UK), Genk } \\
\text { (Belgium), and } \\
\text { Poznań (Poland) }\end{array}$ & $\begin{array}{l}\text { European Union } \\
\text { Horizon } 2020 \\
\text { program with } \\
\text { the project } \\
\text { Connecting } \\
\text { Nature } \\
(2017-2021)\end{array}$ & Land Use Policy & $\begin{array}{l}\text { Presented a } \\
\text { conceptual } \\
\text { framework of } \\
\text { policy needs for } \\
\text { analyzing the } \\
\text { science of NBS' } \\
\text { implementation } \\
\text { and connected it } \\
\text { to the practice of } \\
\text { their } \\
\text { implementation } \\
\text { that advances } \\
\text { the literature by } \\
\text { connecting } \\
\text { well-researched } \\
\text { gaps to a more } \\
\text { innovative } \\
\text { action-oriented } \\
\text { policy } \\
\text { development } \\
\text { approach that we } \\
\text { argue is required } \\
\text { for embedding } \\
\text { scaled-up } \\
\text { nature-based } \\
\text { solutions. }\end{array}$ & $\begin{array}{l}\text { The cross-case } \\
\text { study analysis } \\
\text { points to the } \\
\text { knowledge } \\
\text { needs of systems' } \\
\text { thinking and } \\
\text { solutions- } \\
\text { oriented } \\
\text { thinking as } \\
\text { paramount for } \\
\text { implementing } \\
\text { nature-based } \\
\text { solutions. Our } \\
\text { analysis further } \\
\text { points to the } \\
\text { skills' needs of } \\
\text { negotiation and } \\
\text { collaboration for } \\
\text { administrative } \\
\text { silo bridging and } \\
\text { for forging } \\
\text { multi-sectoral } \\
\text { partnerships } \\
\text { essential for } \\
\text { planning, and } \\
\text { comanaging } \\
\text { NBS.Three ways } \\
\text { forward to } \\
\text { addressing the } \\
\text { policy needs for } \\
\text { implementation: } \\
\text { (1) Cities can } \\
\text { invest in tailored } \\
\text { and targeted } \\
\text { capacity- } \\
\text { building } \\
\text { programs; }(2) \\
\text { institutional } \\
\text { spaces need to be } \\
\text { established that } \\
\text { allow for } \\
\text { collaborative } \\
\text { learning through } \\
\text { and for } \\
\text { partnerships; } \\
\text { and (3) cities } \\
\text { need to chart } \\
\text { governance } \\
\text { innovations that } \\
\text { promote } \\
\text { evidence-based } \\
\text { policy for } \\
\text { nature-based } \\
\text { solutions' design } \\
\text { and } \\
\text { implementation. }\end{array}$ \\
\hline
\end{tabular}


Table A3. Cont.

\begin{tabular}{|c|c|c|c|c|c|c|c|}
\hline Title & Thematic Goals & Specific Themes & $\begin{array}{c}\text { Study } \\
\text { Continents and } \\
\text { Case Study }\end{array}$ & Funding Name & Source Title & Contribution & Recommendation \\
\hline $\begin{array}{l}\text { Introducing } \\
\text { nature-based } \\
\text { solutions into } \\
\text { urban } \\
\text { policy-facts and } \\
\text { gaps. Case study } \\
\text { of Poznan [73] }\end{array}$ & $1+2+3+4$ & Integrated & $\begin{array}{l}\text { EU_Poznań, } \\
\text { Poland }\end{array}$ & $\begin{array}{l}\text { European } \\
\text { Commission's } \\
\text { Horizon } 2020 \\
\text { research and } \\
\text { innovation } \\
\text { program }\end{array}$ & Land Use Policy & $\begin{array}{l}\text { (1) Diagnosing of } \\
\text { current position } \\
\text { NbS in the tasks } \\
\text { and directions of } \\
\text { planning, } \\
\text { strategic and } \\
\text { programming } \\
\text { documents; (2) } \\
\text { characteristic of } \\
\text { activities related } \\
\text { to NbS according } \\
\text { to the form of } \\
\text { human-nature } \\
\text { interaction; (3) } \\
\text { determining the } \\
\text { potential of } \\
\text { including NbS in } \\
\text { the local policy; } \\
\text { (4) identifying } \\
\text { the role of NbS is } \\
\text { facing four main } \\
\text { challenges in } \\
\text { urban policy: } \\
\text { Resilience and } \\
\text { climate change } \\
\text { adaptation, } \\
\text { health, and } \\
\text { wellbeing, social } \\
\text { cohesion, } \\
\text { economic } \\
\text { development } \\
\text { potential. }\end{array}$ & $\begin{array}{l}\text { (1) Need } \\
\text { evidence: The } \\
\text { possibility to } \\
\text { build and } \\
\text { strengthen social } \\
\text { cohesion based } \\
\text { on GI; the } \\
\text { influence of NbS } \\
\text { on the economic } \\
\text { development } \\
\text { potential; (2) } \\
\text { upscale NBS } \\
\text { need bring them } \\
\text { into the local } \\
\text { urban agenda. } \\
\text { An evaluation of } \\
\text { urban policy } \\
\text { documents } \\
\text { based on the } \\
\text { presented } \\
\text { approach can } \\
\text { serve as a } \\
\text { guideline for } \\
\text { identifying gaps } \\
\text { and potentials } \\
\text { for NbS } \\
\text { inclusion. As a } \\
\text { result, it can help } \\
\text { the better } \\
\text { organization of } \\
\text { urban policy and } \\
\text { harmonization of } \\
\text { different sectors } \\
\text { through NBS. }\end{array}$ \\
\hline $\begin{array}{c}\text { Nature-based } \\
\text { solutions for } \\
\text { urban } \\
\text { biodiversity } \\
\text { governance [84] }\end{array}$ & 3 & Biodiversity & $\begin{array}{l}\text { EU-199 NBS } \\
\text { projects in EU }\end{array}$ & $\begin{array}{c}\text { European } \\
\text { Commission's } \\
\text { Horizon } 2020 \\
\text { research and } \\
\text { innovation } \\
\text { program and } \\
\text { participating } \\
\text { partners in the } \\
\text { NATURVATION } \\
\text { project }\end{array}$ & $\begin{array}{l}\text { Environmental } \\
\text { Science and } \\
\text { Policy }\end{array}$ & $\begin{array}{l}\text { (1) Identified } \\
\text { how cities work } \\
\text { with NBS to } \\
\text { conserve nature, } \\
\text { restore nature, } \\
\text { and to find ways } \\
\text { to thrive through } \\
\text { harnessing } \\
\text { nature's } \\
\text { contribution to } \\
\text { people; (2) found } \\
\text { European cities } \\
\text { are taking } \\
\text { project-based } \\
\text { actions for } \\
\text { biodiversity } \\
\text { through a set of } \\
\text { explicit, } \\
\text { quantitative, and } \\
\text { measurable } \\
\text { targets, which } \\
\text { are tailored to } \\
\text { the specific } \\
\text { conditions of } \\
\text { urban settings. }\end{array}$ & $\begin{array}{c}\text { New } \\
\text { international } \\
\text { frameworks } \\
\text { being developed } \\
\text { for the post-2020 } \\
\text { period should } \\
\text { include targets } \\
\text { that } \\
\text { acknowledge the } \\
\text { way in which } \\
\text { biodiversity is } \\
\text { governed in } \\
\text { cities and the } \\
\text { contribution that } \\
\text { cities make to } \\
\text { conserve, restore } \\
\text { and thrive with } \\
\text { nature to guide } \\
\text { urban action. }\end{array}$ \\
\hline
\end{tabular}


Table A3. Cont.

\begin{tabular}{|c|c|c|c|c|c|c|c|}
\hline Title & Thematic Goals & Specific Themes & $\begin{array}{c}\text { Study } \\
\text { Continents and } \\
\text { Case Study }\end{array}$ & Funding Name & Source Title & Contribution & Recommendation \\
\hline $\begin{array}{l}\text { Volunteered } \\
\text { information on } \\
\text { nature-based } \\
\text { solutions- } \\
\text { Dredging for } \\
\text { data on } \\
\text { deculverting [85] }\end{array}$ & $1+2+3+4$ & Urban water & $\begin{array}{c}\text { EU- } \\
\text { Deculverting } \\
\text { projects: Urban } \\
\text { and rural } \\
\text { daylighting of } \\
\text { culverted } \\
\text { stretches of the } \\
\text { Porter Brook, } \\
\text { Sheffield, UK }\end{array}$ & $\begin{array}{c}\text { UK } \\
\text { (EPSRC-funded } \\
\text { project) }\end{array}$ & $\begin{array}{l}\text { Urban Forestry } \\
\text { and Urban } \\
\text { Greening }\end{array}$ & $\begin{array}{l}\text { (1) Reported on } \\
\text { experiences with } \\
\text { gathering } \\
\text { information } \\
\text { using a } \\
\text { 'bottom-up' } \\
\text { map-based wiki } \\
\text { tool from the } \\
\text { public and } \\
\text { professional } \\
\text { stakeholders; (2) } \\
\text { reflected on our } \\
\text { approach, the } \\
\text { opportunities } \\
\text { presented, } \\
\text { constraints } \\
\text { encountered, } \\
\text { progress made } \\
\text { and results } \\
\text { delivered, } \\
\text { contrasted with } \\
\text { other resources } \\
\text { and } \\
\text { data-gathering } \\
\text { projects having } \\
\text { similar aims for } \\
\text { different urban } \\
\text { NBS. }\end{array}$ & $\begin{array}{l}\text { (1) Findings } \\
\text { covered the } \\
\text { substantive issue } \\
\text { of the uptake of } \\
\text { deculverting as a } \\
\text { particular form } \\
\text { of NBS, } \\
\text { including } \\
\text { land-use } \\
\text { contexts, scheme } \\
\text { costs, and } \\
\text { achievement of } \\
\text { stated objectives; } \\
\text { (2) reflections are } \\
\text { given on } \\
\text { potential } \\
\text { contributions of } \\
\text { such methods in } \\
\text { relation to other, } \\
\text { more established } \\
\text { approaches and } \\
\text { new techniques } \\
\text { in urban } \\
\text { knowledge } \\
\text { coproduction. }\end{array}$ \\
\hline $\begin{array}{l}\text { How 'just' is } \\
\text { hybrid } \\
\text { governance of } \\
\text { urban } \\
\text { nature-based } \\
\text { solutions? [81] }\end{array}$ & 1 & Integrated & $\begin{array}{c}\text { Global-6 cases } \\
\text { globally (Greece, } \\
\text { Canada, UK, } \\
\text { Mexico, China) }\end{array}$ & $\begin{array}{c}\text { European } \\
\text { Commission's } \\
\text { Horizon } 2020 \\
\text { research and } \\
\text { innovation } \\
\text { program and } \\
\text { participating } \\
\text { partners in the } \\
\text { Naturvation } \\
\text { project }\end{array}$ & Cities & $\begin{array}{l}\text { Offer guidance } \\
\text { to realize the } \\
\text { current wave of } \\
\text { hybrid } \\
\text { governance of } \\
\text { urban NBS in a } \\
\text { 'just' way. } \\
\text { Exploring the } \\
\text { tensions between } \\
\text { these justice } \\
\text { impacts, we } \\
\text { formulate three } \\
\text { main policy } \\
\text { implications for } \\
\text { hybrid } \\
\text { governance } \\
\text { settings: The } \\
\text { need for } \\
\text { transparent } \\
\text { decision-making } \\
\text { on the } \\
\text { distribution of } \\
\text { costs and } \\
\text { benefits; } \\
\text { safeguarding } \\
\text { public control } \\
\text { over the urban } \\
\text { NBS, and the use } \\
\text { of scientific } \\
\text { expertise in } \\
\text { combination } \\
\text { with bottom-up } \\
\text { consultation } \\
\text { procedures to } \\
\text { recognize both } \\
\text { current and } \\
\text { future voices. }\end{array}$ & $\begin{array}{l}\text { We recommend } \\
\text { future research } \\
\text { to add empirical } \\
\text { insights that } \\
\text { further flesh out } \\
\text { these three rec- } \\
\text { ommendations } \\
\text { (slicing a bigger } \\
\text { pie, safeguarding } \\
\text { democratic } \\
\text { control, and } \\
\text { context-sensitive } \\
\text { science), } \\
\text { providing } \\
\text { further empirical } \\
\text { support and } \\
\text { direction for } \\
\text { operationalizing } \\
\text { 'just' hybrid } \\
\text { governance of } \\
\text { urban NBS. }\end{array}$ \\
\hline
\end{tabular}


Table A3. Cont.

\begin{tabular}{|c|c|c|c|c|c|c|c|}
\hline Title & Thematic Goals & Specific Themes & $\begin{array}{c}\text { Study } \\
\text { Continents and } \\
\text { Case Study }\end{array}$ & Funding Name & Source Title & Contribution & Recommendation \\
\hline $\begin{array}{c}\text { Nature-Based } \\
\text { Solutions for } \\
\text { Urban Climate } \\
\text { Change } \\
\text { Adaptation: } \\
\text { Linking Science, } \\
\text { Policy, and } \\
\text { Practice } \\
\text { Communities for } \\
\text { Evidence-Based } \\
\text { Decision-Making } \\
\text { [82] }\end{array}$ & $2+4$ & $\begin{array}{l}\text { Climate change } \\
\text { adaptation }\end{array}$ & $\begin{array}{c}\text { Global-City of } \\
\text { Melbourne } \\
\text { Urban Forest } \\
\text { Fund, Australia; } \\
\text { Linking } \\
\text { nature-based } \\
\text { solutions and } \\
\text { urban greening } \\
\text { in Dares Salaam, } \\
\text { Tanzania }\end{array}$ & $\begin{array}{c}\text { EU, US, } \\
\text { Australia } \\
\text { (European } \\
\text { Community's } \\
\text { Framework } \\
\text { Program } \\
\text { Horizon 2020; } \\
\text { National Science } \\
\text { Foundation's } \\
\text { project; the } \\
\text { European Joint } \\
\text { Program } \\
\text { Initiative } \\
\text { Biodiversa } \\
\text { ENABLE project, } \\
\text { and the } \\
\text { Australian } \\
\text { Research } \\
\text { Council) }\end{array}$ & Bioscience & $\begin{array}{l}\text { (1) Address } \\
\text { interlocking } \\
\text { questions about } \\
\text { the evidence and } \\
\text { knowledge } \\
\text { needed for } \\
\text { integrating NBS } \\
\text { into urban } \\
\text { agendas; (2) } \\
\text { elaborate on the } \\
\text { ways to advance } \\
\text { the planning and } \\
\text { knowledge } \\
\text { agenda for NBS; } \\
\text { (3) open a wider } \\
\text { discussion on } \\
\text { how cities can } \\
\text { effectively } \\
\text { mainstream NBS } \\
\text { to mitigate and } \\
\text { adapt to the } \\
\text { negative effects } \\
\text { of climate } \\
\text { change and the } \\
\text { future role of } \\
\text { urban science in } \\
\text { coproducing } \\
\text { NBS. }\end{array}$ & $\begin{array}{l}\text { Three suggested } \\
\text { ways forward: } \\
\text { (1) Collaborative } \\
\text { research and } \\
\text { knowledge } \\
\text { coproduction; (2) } \\
\text { Indicators and } \\
\text { the role of big } \\
\text { data; (3) } \\
\text { investment } \\
\text { models and } \\
\text { novel financing. }\end{array}$ \\
\hline $\begin{array}{l}\text { Innovative urban } \\
\text { forestry } \\
\text { governance in } \\
\text { Melbourne: } \\
\text { Investigating } \\
\text { green } \\
\text { placemaking as a } \\
\text { nature-based } \\
\text { solution [88] }\end{array}$ & 1 & Urban forestry & $\begin{array}{l}\text { Oceania- } \\
\text { Melbourne, } \\
\text { Australia }\end{array}$ & No & $\begin{array}{l}\text { Environmental } \\
\text { Research }\end{array}$ & $\begin{array}{l}\text { (1) Contribute to } \\
\text { this } \\
\text { re-assessment of } \\
\text { urban } \\
\text { environmental } \\
\text { governance by } \\
\text { examining the } \\
\text { City of } \\
\text { Melbourne's } \\
\text { approach to } \\
\text { urban } \\
\text { re-naturing } \\
\text { governance from } \\
\text { a place-based } \\
\text { perspective; (2) } \\
\text { investigated how } \\
\text { and to which } \\
\text { extent the } \\
\text { governance } \\
\text { arrangements } \\
\text { embedded } \\
\text { within the urban } \\
\text { forest strategy } \\
\text { (UFS) draw } \\
\text { strength from } \\
\text { diverse } \\
\text { perspectives and } \\
\text { allow for } \\
\text { institutional } \\
\text { arrangements } \\
\text { that support } \\
\text { "situated" } \\
\text { reflexive } \\
\text { decision making } \\
\text { and cocreation; } \\
\text { (3) provided } \\
\text { valuable insight } \\
\text { for the broader } \\
\text { UGI governance } \\
\text { field regarding } \\
\text { the opportunities } \\
\text { and challenges } \\
\text { associated with a } \\
\text { socio-cultural } \\
\text { approach to } \\
\text { urban } \\
\text { re-naturing and } \\
\text { ES delivery. }\end{array}$ & $\begin{array}{l}\text { (1) Include } \\
\text { "other } \\
\text { knowledge } \\
\text { systems outside } \\
\text { modern science", } \\
\text { such as local } \\
\text { place-based } \\
\text { perspectives and } \\
\text { actively facilitate } \\
\text { pluralistic views } \\
\text { of landscape } \\
\text { based in hybrid } \\
\text { understandings } \\
\text { of place; (2) } \\
\text { challenges of } \\
\text { ecological } \\
\text { gentrification } \\
\text { and } \\
\text { institutionalized } \\
\text { hierarchies of } \\
\text { cultural } \\
\text { representation } \\
\text { must be taken } \\
\text { seriously by } \\
\text { politicians, } \\
\text { community, and } \\
\text { academics alike } \\
\text { and warrant } \\
\text { in-depth future } \\
\text { studies. }\end{array}$ \\
\hline
\end{tabular}


Table A3. Cont.

\begin{tabular}{|c|c|c|c|c|c|c|c|}
\hline Title & Thematic Goals & Specific Themes & $\begin{array}{c}\text { Study } \\
\text { Continents and } \\
\text { Case Study }\end{array}$ & Funding Name & Source Title & Contribution & Recommendation \\
\hline $\begin{array}{l}\text { Polycentric } \\
\text { governance in } \\
\text { nature-based } \\
\text { solutions: } \\
\text { insights from } \\
\text { Melbourne } \\
\text { urban forest } \\
\text { managers [125] }\end{array}$ & 1 & Urban forestry & Oceania & No & $\begin{array}{l}\text { Landscape } \\
\text { Architecture } \\
\text { Frontiers }\end{array}$ & $\begin{array}{l}\text { (1) Explored how } \\
\text { polycentric } \\
\text { governance of } \\
\text { urban forests } \\
\text { may operate by } \\
\text { focusing on how } \\
\text { key } \\
\text { decision-makers } \\
\text { coordinate their } \\
\text { priorities and } \\
\text { actions in urban } \\
\text { forestry } \\
\text { decisions; (2) } \\
\text { developed a } \\
\text { better } \\
\text { understanding of } \\
\text { the social } \\
\text { systems behind } \\
\text { the } \\
\text { implementation } \\
\text { of NBS. }\end{array}$ & $\begin{array}{l}\text { (1) Engaging } \\
\text { these key } \\
\text { decision-makers, } \\
\text { as well as } \\
\text { understanding } \\
\text { their concerns } \\
\text { and challenges, } \\
\text { is fundamental } \\
\text { to understand } \\
\text { how polycentric } \\
\text { governance is } \\
\text { implemented in } \\
\text { an NBS context; } \\
\text { (2) further } \\
\text { research is } \\
\text { needed on how } \\
\text { non- } \\
\text { governmental } \\
\text { groups } \\
\text { participate in the } \\
\text { systemic } \\
\text { governance of } \\
\text { urban trees in } \\
\text { both public and } \\
\text { private, formal } \\
\text { and informal } \\
\text { spaces, to } \\
\text { understand what } \\
\text { these key } \\
\text { capacities are, } \\
\text { where they exist, } \\
\text { and how they } \\
\text { can effectively } \\
\text { help implement } \\
\text { NBS } \\
\text { systematically; } \\
\text { (3) aspects of } \\
\text { governance like } \\
\text { coordination of } \\
\text { stakeholders, } \\
\text { funding, staffing, } \\
\text { community } \\
\text { support, } \\
\text { monitoring } \\
\text { programs, and } \\
\text { lack of } \\
\text { knowledge, can } \\
\text { all affect urban } \\
\text { forest } \\
\text { vulnerability. }\end{array}$ \\
\hline
\end{tabular}

\section{References}

1. Fritz, M. Nature-Based Solutions for Societal Goals Under Climate Change in Urban Areas—Synthesis and Ways Forward. In Nature-Based Solutions to Climate Change Adaptation in Urban Areas: Linkages between Science, Policy and Practice; Kabisch, N., Korn, H., Stadler, J., Bonn, A., Eds.; Theory and Practice of Urban Sustainability Transitions; Springer International Publishing Ag.: Gewerbestrasse, Switzerland, 2017; pp. 323-336. [CrossRef]

2. Cohen-Shacham, G.; Walters, G.; Janzen, C.; Maginnis, S. (Eds.) Nature-Based Solutions to Address Global Societal Challenges; IUCN (International Union for Conservation of Nature): Gland, Switzerland, 2016.

3. European Commission. Towards an EU Research and Innovation Policy Agenda for Nature-Based Solutions E Re-Naturing Cities Final Report of the Horizon 2020 Expert Group on "Nature-Based Solutions and Re-Naturing Cities"; European Commission: Brussels, Belgium, 2015; Volume 1. [CrossRef]

4. $\quad$ Eggermont, H.; Balian, E.; Azevedo, J.M.N.; Beumer, V.; Brodin, T.; Claudet, J.; Fady, B.; Grube, M.; Keune, H.; Lamarque, P.; et al. Nature-Based Solutions: New Influence for Environmental Management and Research in Europe. Gaia 2015, 24, 243-248. [CrossRef]

5. Albert, C.; Brillinger, M.; Guerrero, P.; Gottwald, S.; Henze, J.; Schmidt, S.; Ott, E.; Schröter, B. Planning Nature-Based Solutions: Principles, Steps, and Insights. Ambio 2020. [CrossRef] [PubMed]

6. Potschin, M.; Kretsch, C.; Haines-, R.; Unott, Y.; Syke, E.F. Nature-Based Solutions. EC FP7 Grant Agreement (308428). 2016. Available online: https://www.researchgate.net/publication/280067191_Nature-Based_Solutions (accessed on 19 January 2021).

7. Faivre, N.; Fritz, M.; Freitas, T.; de Boissezon, B.; Vandewoestijne, S. Nature-Based Solutions in the EU: Innovating with Nature to Address Social, Economic and Environmental Challenges. Environ. Res. 2017, 159, 509-518. [CrossRef] [PubMed]

8. Fritz, M. Urban Gardens as Multifunctional Nature-Based Solutions for Societal Goals in a Changing Climate. In Nature-Based Solutions to Climate Change Adaptation in Urban Areas: Linkages between Science, Policy and Practice; Kabisch, N., Korn, H., Stadler, J., 
Bonn, A., Eds.; Theory and Practice of Urban Sustainability Transitions; Springer International Publishing AG: Gewerbestrasse, Switzerland, 2017; pp. 237-253. [CrossRef]

9. McKenna, D.; Abhold, K.; Mederake, L.; Knoblauch, D. NBS in European and National Policy Framework. Naturvation 2018, 50, $1-52$.

10. Langemeyer, J.; Camps-Calvet, M.; Calvet-Mir, L.; Barthel, S.; Gómez-Baggethun, E. Stewardship of Urban Ecosystem Services: Understanding the Value(s) of Urban Gardens in Barcelona. Landsc. Urban Plan. 2018, 170, 79-89. [CrossRef]

11. Nesshöver, C.; Assmuth, T.; Irvine, K.N.; Rusch, G.M.; Waylen, K.A.; Delbaere, B.; Haase, D.; Jones-Walters, L.; Keune, H.; Kovacs, E.; et al. The Science, Policy and Practice of Nature-Based Solutions: An Interdisciplinary Perspective. Sci. Total Environ. 2017, 579, 1215-1227. [CrossRef] [PubMed]

12. Maes, J.; Jacobs, S. Nature-Based Solutions for Europe's Sustainability able Development. Conserv. Lett. 2017, 10, 121-124. [CrossRef]

13. Cheshmehzangi, A. China's New-Type Urbanisation Plan (NUP) and the Foreseeing Challenges for Decarbonization of Cities: A Review. Energy Procedia 2016, 104, 146-152. [CrossRef]

14. Fini, A.; Frangi, P.; Mori, J.; Donzelli, D.; Ferrini, F. Nature Based Solutions to Mitigate Soil Sealing in Urban Areas: Results from a 4-Year Study Comparing Permeable, Porous, and Impermeable Pavements. Environ. Res. 2017, 156, 443-454. [CrossRef]

15. Zoelch, T.; Henze, L.; Keilholz, P.; Pauleit, S. Regulating Urban Surface Runoff through Nature-Based Solutions-An Assessment at the Micro-Scale. Environ. Res. 2017, 157, 135-144. [CrossRef]

16. Dondajewska, R.; Kozak, A.; Budzyńska, A.; Kowalczewska-Madura, K.; Gołdyn, R. Nature-Based Solutions for Protection and Restoration of Degraded Bielsko Lake. Ecohydrol. Hydrobiol. 2018, 18, 401-411. [CrossRef]

17. Gearey, M. Re-Naturing Cities: Reducing Flood Risk through Nature Based Solutions. Geography 2018, 103, 105-109. [CrossRef]

18. Connop, S.; Vandergert, P.; Eisenberg, B.; Collier, M.J.; Nash, C.; Clough, J.; Newport, D. Renaturing Cities Using a RegionallyFocused Biodiversity-Led Multifunctional Benefits Approach to Urban Green Infrastructure. Environ. Sci. Policy 2016, 62, 99-111. [CrossRef]

19. Xie, L.; Flynn, A.; Tan-Mullins, M.; Cheshmehzangi, A. Water and Land: Environmental Governance and Chinese EcoDevelopment. J. Clean. Prod. 2019, 211, 839-853. [CrossRef]

20. Gopalakrishnan, V.; Ziv, G.; Bakshi, B.R. Role of Vegetation in Mitigating Air Emissions Across Industrial Sites in the US. ACS Sustain. Chem. Eng. 2019, 7, 3783-3791. [CrossRef]

21. Marando, F.; Salvatori, E.; Fusaro, L.; Manes, F. Removal of PM10 by Forests as a Nature-Based Solution for Air Quality Improvement in the Metropolitan City of Rome. Forests 2016, 7, 150. [CrossRef]

22. McVittie, A.; Cole, L.; Wreford, A.; Sgobbi, A.; Yordi, B. Ecosystem-Based Solutions for Disaster Risk Reduction: Lessons from European Applications of Ecosystem-Based Adaptation Measures. Int. J. Disaster Risk Reduct. 2018, 32, 42-54. [CrossRef]

23. Dorst, H.; van der Jagt, A.; Raven, R.; Runhaar, H. Urban Greening through Nature-Based Solutions-Key Characteristics of an Emerging Concept. Sustain. Cities Soc. 2019, 49, 101620. [CrossRef]

24. Van der Jagt, A.P.N.; Szaraz, L.R.; Delshammar, T.; Cvejic, R.; Santos, A.; Goodness, J.; Buijs, A. Cultivating Nature-Based Solutions: The Governance of Communal Urban Gardens in the European Union. Environ. Res. 2017, 159, 264-275. [CrossRef] [PubMed]

25. Van den Bosch, M.; Ode, S. Urban Natural Environments as Nature-Based Solutions for Improved Public Health-A Systematic Review of Reviews. Environ. Res. 2017, 158, 373-384. [CrossRef] [PubMed]

26. Kabisch, N.; van den Bosch, M.; Lafortezza, R. The Health Benefits of Nature-Based Solutions to Urbanization Challenges for Children and the Elderly-A Systematic Review. Environ. Res. 2017, 159, 362-373. [CrossRef]

27. Song, Y.; Kirkwood, N.; Maksimović, Č.; Zhen, X.; O'Connor, D.; Jin, Y.; Hou, D. Nature Based Solutions for Contaminated Land Remediation and Brownfield Redevelopment in Cities: A Review. Sci. Total Environ. 2019, 663, 568-579. [CrossRef] [PubMed]

28. Artmann, M.; Sartison, K. The Role of Urban Agriculture as a Nature-Based Solution: A Review for Developing a Systemic Assessment Framework. Sustainability 2018, 10, 1937. [CrossRef]

29. Xing, Y.; Jones, P.; Donnison, I. Characterisation of Nature-Based Solutions for the Built Environment. Sustainability 2017, 9 , 149. [CrossRef]

30. Zari, M.P.; Kiddle, G.L.; Blaschke, P.; Gawler, S.; Loubser, D. Utilising Nature-Based Solutions to Increase Resilience in Pacific Ocean Cities. Ecosyst. Serv. 2019, 38. [CrossRef]

31. Ruangpan, L.; Vojinovic, Z.; Di Sabatino, S.; Sandra Leo, L.; Capobianco, V.; Oen, A.M.P.; Mcclain, M.E.; Lopez-Gunn, E. Nature-Based Solutions for Hydro-Meteorological Risk Reduction: A State-of-the-Art Review of the Research Area. Nat. Hazards Earth Syst. Sci. 2020, 20, 243-270. [CrossRef]

32. Nika, C.E.; Gusmaroli, L.; Ghafourian, M.; Atanasova, N.; Buttiglieri, G.; Katsou, E. Nature-Based Solutions as Enablers of Circularity in Water Systems: A Review on Assessment Methodologies, Tools and Indicators. Water Res. 2020, $183,115988$. [CrossRef]

33. Huang, Y.; Tian, Z.; Ke, Q.; Liu, J.; Irannezhad, M.; Fan, D.; Hou, M.; Sun, L. Nature-based Solutions for Urban Pluvial Flood Risk Management. Wires Water 2020, 1-17. [CrossRef]

34. Padma, P.; Ramakrishna, S.; Rasoolimanesh, S.M. Nature-Based Solutions in Tourism: A Review of the Literature and Conceptualization. J. Hosp. Tour. Res. 2019. [CrossRef] 
35. Escobedo, F.J.; Giannico, V.; Jim, C.Y.; Sanesi, G.; Lafortezza, R. Urban Forests, Ecosystem Services, Green Infrastructure and Nature-Based Solutions: Nexus or Evolving Metaphors. Urban For. Urban Green. 2019, 37, 3-12. [CrossRef]

36. Sarabi, S.E.; Han, Q.; Romme, A.G.L.; de Vries, B.; Wendling, L. Key Enablers of and Barriers to the Uptake and Implementation of Nature-Based Solutions in Urban Settings: A Review. Resources 2019, 8, 121. [CrossRef]

37. Ferreira, V.; Barreira, A.P.; Loures, L.; Antunes, D.; Panagopoulos, T. Stakeholders' Engagement on Nature-Based Solutions: A Systematic Literature Review. Sustainability 2020, 12, 640. [CrossRef]

38. Garfield, E. Citation Indexes for Science: A New Dimension in Documentation through Association of Ideas. Science 1955, 122, 108-111. [CrossRef]

39. Otte, E.; Rousseau, R. Social Network Analysis: A Powerful Strategy, Also for the Information Sciences. J. Inf. Sci. 2002, 28, 441-453. [CrossRef]

40. Borgatti, S.P.; Everett, M.G.; Freeman, L.C. Ucinet for Windows: Software for Social Network Analysis; Analytic Technologies: Harvard, MA, USA, 2002; Available online: https:/ / sites.google.com/site/ucinetsoftware/home (accessed on 30 March 2021).

41. Hansen, D.L.; Shneiderman, B.; Smith, M.A. Analyzing Social Media Networks With NodeXL; Morgan Kaufmann: Burlington, MA, USA, 2011. [CrossRef]

42. Barabási, A.L.; Oltvai, Z.N. Network Biology: Understanding the Cell's Functional Organization. Nat. Rev. Genet. 2004. [CrossRef]

43. Basler, G.; Nikoloski, Z.; Larhlimi, A.; Barabási, A.L.; Liu, Y.Y. Control of Fluxes in Metabolic Networks. Genome Res. 2016. [CrossRef]

44. Ravindran, V.; Nacher, J.C.; Akutsu, T.; Ishitsuka, M.; Osadcenco, A.; Sunitha, V.; Bagler, G.; Schwartz, J.M.; Robertson, D.L. Network Controllability Analysis of Intracellular Signalling Reveals Viruses Are Actively Controlling Molecular Systems. Sci. Rep. 2019. [CrossRef]

45. Barabási, A.L.; Gulbahce, N.; Loscalzo, J. Network Medicine: A Network-Based Approach to Human Disease. Nat. Rev. Genet. 2011. [CrossRef]

46. De Montis, A.; Caschili, S.; Mulas, M.; Modica, G.; Ganciu, A.; Bardi, A.; Ledda, A.; Dessena, L.; Laudari, L.; Fichera, C.R. Urban-Rural Ecological Networks for Landscape Planning. Land Use Policy 2016. [CrossRef]

47. De Montis, A.; Ganciu, A.; Cabras, M.; Bardi, A.; Peddio, V.; Caschili, S.; Massa, P.; Cocco, C.; Mulas, M. Resilient Ecological Networks: A Comparative Approach. Land Use Policy 2019. [CrossRef]

48. Caschili, S.; De Montis, A.; Ganciu, A.; Ledda, A.; Barra, M. The Strategic Environment Assessment Bibliographic Network: A Quantitative Literature Review Analysis. Environ. Impact Assess. Rev. 2014. [CrossRef]

49. Manolache, S.; Nita, A.; Ciocanea, C.M.; Popescu, V.D.; Rozylowicz, L. Power, Influence and Structure in Natura 2000 Governance Networks. A Comparative Analysis of Two Protected Areas in Romania. J. Environ. Manag. 2018. [CrossRef]

50. Sharifi, A. Trade-Offs and Conflicts between Urban Climate Change Mitigation and Adaptation Measures: A Literature Review. J. Clean. Prod. 2020, 276. [CrossRef]

51. Deng, H.M.; Liang, Q.M.; Liu, L.J.; Anadon, L.D. Co-Benefits of Greenhouse Gas Mitigation: A Review and Classification by Type, Mitigation Sector, and Geography. Environ. Res. Lett. 2017, 12. [CrossRef]

52. Li, Z.; Xu, S.; Yao, L. A Systematic Literature Mining of Sponge City: Trends, Foci and Challenges Standing Ahead. Sustainability 2018, 10, 1182. [CrossRef]

53. Badiu, D.L.; Nita, A.; Iojă, C.I.; Niţă, M.R. Disentangling the Connections: A Network Analysis of Approaches to Urban Green Infrastructure. Urban For. Urban Green. 2019, 41, 211-220. [CrossRef]

54. Scott, M.; Lennon, M.; Haase, D.; Kazmierczak, A.; Clabby, G.; Beatley, T. Nature-Based Solutions for the Contemporary City /ReNaturing the City/Reflections on Urban Landscapes, Ecosystems Services and Nature-Based Solutions in Cities/Multifunctional Green Infrastructure and Climate Change Adaptation: Brownfield Greening as an Adaptation Strategy for Vulnerable Communities? Delivering Green Infrastructure through Planning: Insights from Practice in Fingal, Ireland/Planning for Biophilic Cities: From Theory to Practice. Plan. Theory Pract. 2016, 17, 267-300. [CrossRef]

55. Sekulova, F.; Anguelovski, I. The Governance and Politics of Nature-Based Solutions. Available online: https://naturvation. eu/sites/default/files/news / files/naturvation_the_governance_and_politics_of_nature-based_solutions.pdf (accessed on 30 March 2021).

56. Cui, Y.; Liu, Y.; Mou, J. Bibliometric Analysis of Organisational Culture Using CiteSpace. S. Afr. J. Econ. Manag. Sci. 2018, 21, 1-12. [CrossRef]

57. Sharifi, A. Urban Resilience Assessment: Mapping Knowledge Structure and Trends. Sustainability 2020, 12, 5918. [CrossRef]

58. Moher, D.; Liberati, A.; Tetzlaff, J.; Altman, D.G.; Altman, D.; Antes, G.; Atkins, D.; Barbour, V.; Barrowman, N.; Berlin, J.A.; et al. Preferred Reporting Items for Systematic Reviews and Meta-Analyses: The PRISMA Statement. PLoS Med. 2009, 6. [CrossRef]

59. Cui, H.; Gu, J. Study on the Practical Exploration and Realistic Dilemma of Sponge City Construction from the Perspective of Public Management Based on the Analysis of Research Data from Hubei Province. IOP Conf. Ser. Mater. Sci. Eng. $2018,371$. [CrossRef]

60. Fortunato, S. Community Detection in Graphs. Phys. Rep. 2010. [CrossRef]

61. Mendes, R.; Fidélis, T.; Roebeling, P.; Teles, F. The Institutionalization of Nature-Based Solutions-a Discourse Analysis of Emergent Literature. Resources 2020, 9, 6. [CrossRef]

62. Dotsika, F.; Watkins, A. Identifying Potentially Disruptive Trends by Means of Keyword Network Analysis. Technol. Forecast. Soc. Chang. 2017. [CrossRef] 
63. Van Eck, N.J.; Waltman, L. VOSviewer Manual 1.6.11. Manual 2016, 1, 1-28.

64. Noack, A. Energy Models for Graph Clustering. J. Graph Algorithms Appl. 2007. [CrossRef]

65. Noack, A. Modularity Clustering Is Force-Directed Layout. Phys. Rev. E Stat. Nonlinear Soft Matter Phys. 2009. [CrossRef]

66. Liquete, C.; Udias, A.; Conte, G.; Grizzetti, B.; Masi, F. Integrated Valuation of a Nature-Based Solution for Water Pollution Control. Highlighting Hidden Benefits. Ecosyst. Serv. 2016, 22, 392-401. [CrossRef]

67. Small, H. Co-citation in the Scientific Literature: A New Measure of the Relationship between Two Documents. J. Am. Soc. Inf. Sci. 1973. [CrossRef]

68. Fang, Y.; Yin, J.; Wu, B. Climate Change and Tourism: A Scientometric Analysis Using CiteSpace. J. Sustain. Tour. 2018, 26, 108-126. [CrossRef]

69. Kabisch, N.; Stadler, J.; Korn, H.; Bonn, A. Nature-Based Solutions to Climate Change Mitigation and Adaptation in Urban Areas. Available online: https://www.bfn.de/fileadmin/BfN/service/Dokumente/skripten/Skript446.pdf (accessed on 30 March 2021).

70. Raymond, C.M.; Frantzeskaki, N.; Kabisch, N.; Berry, P.; Breil, M.; Nita, M.R.; Geneletti, D.; Calfapietra, C. A Framework for Assessing and Implementing the Co-Benefits of Nature-Based Solutions in Urban Areas. Environ. Sci. Policy 2017, 77, 15-24. [CrossRef]

71. Frantzeskaki, N. Seven Lessons for Planning Nature-Based Solutions in Cities. Environ. Sci. Policy 2019, 93, 101-111. [CrossRef]

72. Lafortezza, R.; Sanesi, G. Nature-Based Solutions: Settling the Issue of Sustainability able Urbanization. Environ. Res. 2019, 172, 394-398. [CrossRef] [PubMed]

73. Zwierzchowska, I.; Fagiewicz, K.; Ponizy, L.; Lupa, P.; Mizgajski, A. Introducing Nature-Based Solutions into Urban Policy-Facts and Gaps. Case Study of Poznan. Land Use Policy 2019, 85, 161-175. [CrossRef]

74. Hanson, H.I.; Wickenberg, B.; Alkan Olsson, J. Working on the Boundaries-How Do Science Use and Interpret the Nature-Based Solution Concept? Land Use Policy 2020, 90, 104302. [CrossRef]

75. Xiang, P.; Wang, Y.; Deng, Q. Inclusive Nature-Based Solutions for Urban Regeneration in a Natural Disaster Vulnerability Context: A Case Study of Chongqing, China. Sustainability 2017, 9, 1205. [CrossRef]

76. Everard, M.; Ahmed, S.; Gagnon, A.S.; Kumar, P.; Thomas, T.; Sinha, S.; Dixon, H.; Sarkar, S. Can Nature-Based Solutions Contribute to Water Security in Bhopal? Sci. Total Environ. 2020, 723, 138061. [CrossRef] [PubMed]

77. Rigotti, J.A.; Pasqualini, J.P.; Rodrigues, L.R. Nature-Based Solutions for Managing the Urban Surface Runoff: An Application of a Constructed Floating Wetland. Limnetica 2020, 39, 441-454. [CrossRef]

78. Young, A.F.; Marengo, J.A.; Martins Coelho, J.O.; Scofield, G.B.; de Oliveira Silva, C.C.; Prieto, C.C. The Role of Nature-Based Solutions in Disaster Risk Reduction: The Decision Maker's Perspectives on Urban Resilience in Sao Paulo State. Int. J. Disaster Risk Reduct. 2019, 39. [CrossRef]

79. Majidi, A.N.; Vojinovic, Z.; Alves, A.; Weesakul, S.; Sanchez, A.; Boogaard, F.; Kluck, J. Planning Nature-Based Solutions for Urban Flood Reduction and Thermal Comfort Enhancement. Sustainability 2019, 11, 6361. [CrossRef]

80. Droste, N.; Schröter-Schlaack, C.; Hansjürgens, B.; Zimmermann, H. Nature-Based Solutions to Climate Change Adaptation in Urban Areas. In Nature-Based Solutions to Climate Change Adaptation in Urban Areas; Linkages between Science, Policy and Practice; Braubach, M., Egorov, A., Mudu, P., Wolf, T., Ward Thompson, C., Martuzzi, M., Eds.; Springer International Publishing Ag.: Gewerbestrasse, Switzerland, 2017; pp. 187-205. [CrossRef]

81. Toxopeus, H.; Kotsila, P.; Conde, M.; Katona, A.; van der Jagt, A.P.N.; Polzin, F. How 'Just' Is Hybrid Governance of Urban Nature-Based Solutions? Cities 2020, 105, 102839. [CrossRef]

82. Frantzeskaki, N.; McPhearson, T.; Collier, M.J.; Kendal, D.; Bulkeley, H.; Dumitru, A.; Walsh, C.; Noble, K.; Van Wyk, E.; Ordóñez, C.; et al. Nature-Based Solutions for Urban Climate Change Adaptation: Linking Science, Policy, and Practice Communities for Evidence-Based Decision-Making. Bioscience 2019, 69, 455-466. [CrossRef]

83. Wamsler, C.; Wickenberg, B.; Hanson, H.; Alkan Olsson, J.; Stålhammar, S.; Björn, H.; Falck, H.; Gerell, D.; Oskarsson, T.; Simonsson, E.; et al. Environmental and Climate Policy Integration: Targeted Strategies for Overcoming Barriers to Nature-Based Solutions and Climate Change Adaptation. J. Clean. Prod. 2020, 247. [CrossRef]

84. Xie, L.; Bulkeley, H. Nature-Based Solutions for Urban Biodiversity Governance. Environ. Sci. Policy 2020, 1-11. [CrossRef]

85. Wild, T.C.; Dempsey, N.; Broadhead, A.T. Volunteered Information on Nature-Based Solutions-Dredging for Data on Deculverting. Urban For. Urban Green. 2019, 40, 254-263. [CrossRef]

86. Neumann, V.A.; Hack, J. A Methodology of Policy Assessment at the Municipal Level: Costa Rica's Readiness for the Implementation of Nature-Based-Solutions for Urban Stormwater Management. Sustainability 2020, 12, 230. [CrossRef]

87. Qi, Y.; Chan, F.K.S.; Thorne, C.; O’donnell, E.; Quagliolo, C.; Comino, E.; Pezzoli, A.; Li, L.; Griffiths, J.; Sang, Y.; et al. Addressing Challenges of Urban Water Management in Chinese Sponge Cities via Nature-Based Solutions. Water 2021, 13, 900. [CrossRef]

88. Gulsrud, N.M.; Hertzog, K.; Shears, I. Innovative Urban Forestry Governance in Melbourne?: Investigating "Green Placemaking" as a Nature-Based Solution. Environ. Res. 2018, 161, 158-167. [CrossRef]

89. Dick, J.; Miller, J.D.; Carruthers-Jones, J.; Dobel, A.J.; Carver, S.; Garbutt, A.; Hester, A.; Hails, R.; Magreehan, V.; Quinn, M. How Are Nature Based Solutions Contributing to Priority Societal Challenges Surrounding Human Well-Being in the United Kingdom: A Systematic Map Protocol. Environ. Evid. 2019. [CrossRef]

90. Panno, A.; Carrus, G.; Lafortezza, R.; Mariani, L.; Sanesi, G. Nature-Based Solutions to Promote Human Resilience and Wellbeing in Cities during Increasingly Hot Summers. Environ. Res. 2017, 159, 249-256. [CrossRef] 
91. Vujcic, M.; Tomicevic-Dubljevic, J.; Grbic, M.; Lecic-Tosevski, D.; Vukovic, O.; Toskovic, O. Nature Based Solution for Improving Mental Health and Well-Being in Urban Areas. Environ. Res. 2017, 158, 385-392. [CrossRef]

92. Cariñanos, P.; Casares-Porcel, M.; Díaz de la Guardia, C.; Aira, M.J.; Belmonte, J.; Boi, M.; Elvira-Rendueles, B.; De Linares, C.; Fernández-Rodriguez, S.; Maya-Manzano, J.M.; et al. Assessing Allergenicity in Urban Parks: A Nature-Based Solution to Reduce the Impact on Public Health. Environ. Res. 2017, 155, 219-227. [CrossRef]

93. Xiang, P.; Yang, Y.; Li, Z. Theoretical Framework of Inclusive Urban Regeneration Combining Nature-Based Solutions with Society-Based Solutions. J. Urban Plan. Dev. 2020, 146, 1-11. [CrossRef]

94. Fan, P.; Ouyang, Z.; Basnou, C.; Pino, J.; Park, H.; Chen, J. Nature-Based Solutions for Urban Landscapes under PostIndustrialization and Globalization: Barcelona versus Shanghai. Environ. Res. 2017, 156, 272-283. [CrossRef] [PubMed]

95. Fink, H.S. Human-Nature for Climate Action: Nature-Based Solutions for Urban Sustainability. Sustainability 2016, 8, 254. [CrossRef]

96. Pasimeni, M.R.; Valente, D.; Zurlini, G.; Petrosillo, I. The Interplay between Urban Mitigation and Adaptation Strategies to Face Climate Change in Two European Countries. Environ. Sci. Policy 2019, 95, 20-27. [CrossRef]

97. Oral, H.V.; Carvalho, P.; Gajewska, M.; Ursino, N.; Masi, F.; van Hullebusch, E.D.; Kazak, J.K.; Exposito, A.; Cipolletta, G.; Andersen, T.R.; et al. A Review of Nature-Based Solutions for Urban Water Management in European Circular Cities: A Critical Assessment Based on Case Studies and Literature. Blue-Green Syst. 2020, 2, 112-136. [CrossRef]

98. Fletcher, T.D.; Shuster, W.; Hunt, W.F.; Ashley, R.; Butler, D.; Arthur, S.; Trowsdale, S.; Barraud, S.; Semadeni-Davies, A.; BertrandKrajewski, J.L.; et al. SUDS, LID, BMPs, WSUD and More-The Evolution and Application of Terminology Surrounding Urban Drainage. Urban Water J. 2015, 12, 525-542. [CrossRef]

99. Chan, F.K.S.; Griffiths, J.A.; Higgitt, D.; Xu, S.; Zhu, F.; Tang, Y.T.; Xu, Y.; Thorne, C.R. "Sponge City" in China-A Breakthrough of Planning and Flood Risk Management in the Urban Context. Land Use Policy 2018, 76, 772-778. [CrossRef]

100. Blau, M.L.; Luz, F.; Panagopoulos, T. Urban River Recovery Inspired by Nature-Based Solutions and Biophilic Design in Albufeira, Portugal. Land 2018, 7, 141. [CrossRef]

101. Lafortezza, R.; Chen, J.; van den Bosch, C.K.; Randrup, T.B. Nature-Based Solutions for Resilient Landscapes and Cities. Environ. Res. 2018, 165, 431-441. [CrossRef]

102. Schweitzer, J.-P.; Gionfra, S. Nature-Based Education for Resilient Cities. In Lifelong Learning and Education in Healthy and Sustainable Cities; Azeiteiro, U.M., Akerman, M., Filho, W.L., Setti, A.F.F., Brandli, L.L., Eds.; World Sustainability ability Series; Springer International Publishing Ag.: Gewerbestrasse, Switzerland, 2018; pp. 355-376. [CrossRef]

103. Giannakis, E.; Bruggeman, A.; Poulou, D.; Zoumides, C.; Eliades, M. Linear Parks along Urban Rivers: Perceptions of Thermal Comfort and Climate Change Adaptation in Cyprus. Sustainability 2016, 8, 1023. [CrossRef]

104. Sahani, J.; Kumar, P.; Debele, S.; Spyrou, C.; Loupis, M.; Aragão, L.; Porcù, F.; Shah, M.A.R.; Di Sabatino, S. Hydro-Meteorological Risk Assessment Methods and Management by Nature-Based Solutions. Sci. Total Environ. 2019, 696, 133936. [CrossRef]

105. Du, S.; Wang, C.; Shen, J.; Wen, J.; Gao, J.; Wu, J.; Lin, W.; Xu, H. Mapping the Capacity of Concave Green Land in Mitigating Urban Pluvial Floods and Its Beneficiaries. Sustain. Cities Soc. 2019, 44, 774-782. [CrossRef]

106. Brink, E.; Aalders, T.; Adam, D.; Feller, R.; Henselek, Y.; Hoffmann, A.; Ibe, K.; Matthey-Doret, A.; Meyer, M.; Negrut, N.L.; et al. Cascades of Green: A Review of Ecosystem-Based Adaptation in Urban Areas. Glob. Environ. Chang. Policy Dimens. 2016, 36, 111-123. [CrossRef]

107. Fritz, M. Integrating the Grey, Green, and Blue in Cities: Nature-Based Solutions for Climate Change Adaptation and Risk Reduction. In Nature-Based Solutions to Climate Change Adaptation in Urban Areas: Linkages between Science, Policy and Practice; Kabisch, N., Korn, H., Stadler, J., Bonn, A., Eds.; Theory and Practice of Urban Sustainability ability Transitions; Springer International Publishing Ag.: Gewerbestrasse, Switzerland, 2017; pp. 91-109. [CrossRef]

108. Russo, A.; Escobedo, F.J.; Cirella, G.T.; Zerbe, S. Edible Green Infrastructure: An Approach and Review of Provisioning Ecosystem Services and Disservices in Urban Environments. Agric. Ecosyst. Environ. 2017, 242, 53-66. [CrossRef]

109. Camps-Calvet, M.; Langemeyer, J.; Calvet-Mir, L.; Gómez-Baggethun, E. Ecosystem Services Provided by Urban Gardens in Barcelona, Spain: Insights for Policy and Planning. Environ. Sci. Policy 2015, 62, 14-23. [CrossRef]

110. Wai, K.M.; Dai, J.; Yu, P.K.N.; Zhou, X.; Wong, C.M.S. Public Health Risk of Mercury in China through Consumption of Vegetables, a Modelling Study. Environ. Res. 2017, 159, 152-157. [CrossRef]

111. Le Guern, C.; Jean-Soro, L.; Béchet, B.; Lebeau, T.; Bouquet, D. Management Initiatives in Support of the Soil Quality of Urban Allotment Gardens: Examples from Nantes (France). Land Degrad. Dev. 2018, 29, 3681-3692. [CrossRef]

112. Kabisch, N.; Frantzeskaki, N.; Pauleit, S.; Naumann, S.; Davis, M.; Artmann, M.; Haase, D.; Knapp, S.; Korn, H.; Stadler, J.; et al. Nature-Based Solutions to Climate Change Mitigation and Adaptation in Urban Areas: Perspectives on Indicators, Knowledge, Barriers, and Opportunities for Action. Ecol. Soc. 2016, 21, 39. [CrossRef]

113. Marando, F.; Salvatori, E.; Sebastiani, A.; Fusaro, L.; Manes, F. Regulating Ecosystem Services and Green Infrastructure: Assessment of Urban Heat Island Effect Mitigation in the Municipality of Rome, Italy. Ecol. Modell. 2019, 392, 92-102. [CrossRef]

114. Chen, X.; de Vries, S.; Assmuth, T.; Dick, J.; Hermans, T.; Hertel, O.; Jensen, A.; Jones, L.; Kabisch, S.; Lanki, T.; et al. Research Challenges for Cultural Ecosystem Services and Public Health in (Peri-)Urban Environments. Sci. Total Environ. 2019, 651, 2118-2129. [CrossRef] [PubMed]

115. European Commission. Horizon 2020, Work Programme 2018-2020 12. Climate Action, Environment, Resource Efficiency and Raw Materials; European Commission: Brussels, Belgium, 2018. 
116. Pauleit, S.; Zölch, T.; Hansen, R.; Randrup, T.B.; van den Bosch, C.K. Nature-Based Solutions and Climate Change-Four Shades of Green. In Nature-Based Solutions to Climate Change Adaptation in Urban Areas: Linkages between Science, Policy and Practice; Kabisch, N., Korn, H., Stadler, J., Bonn, A., Eds.; Theory and Practice of Urban Sustainability ability Transitions; Springer International Publishing Ag.: Gewerbestrasse, Switzerland, 2017; pp. 29-49. [CrossRef]

117. Tzoulas, K.; Galan, J.; Venn, S.; Dennis, M.; Pedroli, B.; Mishra, H.; Haase, D.; Pauleit, S.; Niemelä, J.; James, P. A Conceptual Model of the Social-Ecological System of Nature-Based Solutions in Urban Environments. Ambio 2020. [CrossRef] [PubMed]

118. Cohen-Shacham, E.; Andrade, A.; Dalton, J.; Dudley, N.; Jones, M.; Kumar, C.; Maginnis, S.; Maynard, S.; Nelson, C.R.; Renaud, F.G.; et al. Core Principles for Successfully Implementing and Upscaling Nature-Based Solutions. Environ. Sci. Policy 2019, 98, 20-29. [CrossRef]

119. Galan, J. Towards a Relational Model for Emerging Urban Nature Concepts: A Practical Application and an External Assessment in Landscape Planning Education. Sustainability 2020, 12, 2465. [CrossRef]

120. Singh, A.; Sarma, A.K.; Hack, J. Cost-Effective Optimization of Nature-Based Solutions for Reducing Urban Floods Considering Limited Space Availability. Environ. Process. 2020, 7, 297-319. [CrossRef]

121. Ranagalage, M.; Ratnayake, S.S.; Dissanayake, D.M.S.L.B.; Kumar, L.; Wickremasinghe, H.; Vidanagama, J.; Cho, H.; Udagedara, S.; Jha, K.K.; Simwanda, M.; et al. Spatiotemporal Variation of Urban Heat Islands for Implementing Nature-Based Solutions: A Case Study of Kurunegala, Sri Lanka. ISPRS Int. J. Geo-Inf. 2020, 9, 461. [CrossRef]

122. Yu, J.; Ariza-Montes, A.; Hernández-Perlines, F.; Vega-Muñoz, A.; Han, H. Hotels' Eco-Friendly Physical Environment as Nature-Based Solutions for Decreasing Burnout and Increasing Job Satisfaction and Performance. Int. J. Environ. Res. Public Health 2020, 17, 6357. [CrossRef]

123. WWAP (United Nations World Water Assessment Programme)/UN-Water. The United Nations World Water Development Report 2018: Nature-Based Solutions for Water; UNESCO: Paris, France, 2018.

124. IIASA-International Institute for Applied Systems Analysis. Governance Innovation through Nature-Based Solutions. 2019. Available online: https:/ /iiasa.ac.at/web/home/resources/publications/IIASAPolicyBriefs/pb25.html (accessed on 30 March 2021).

125. Camilo, O. Polycentric Governance in Nature-Based Solutions: Insights From Melbourne Urban Forest Managers. Landsc. Archit. Front. 2019, 7, 46. [CrossRef]

126. Davies, H.J.; Doick, K.J.; Hudson, M.D.; Schreckenberg, K. Challenges for Tree Officers to Enhance the Provision of Regulating Ecosystem Services from Urban Forests. Environ. Res. 2017, 156, 97-107. [CrossRef]

127. Castonguay, A.C.; Iftekhar, M.S.; Urich, C.; Bach, P.M.; Deletic, A. Integrated Modelling of Stormwater Treatment Systems Uptake. Water Res. 2018, 142, 301-312. [CrossRef]

128. Zhang, S.; Zevenbergen, C.; Rabé, P.; Jiang, Y. The Influences of Sponge City on Property Values in Wuhan, China. Water 2018, 10, 766. [CrossRef]

129. Davies, C.; Lafortezza, R. Transitional Path to the Adoption of Nature-Based Solutions. Land Use Policy 2019, 80, 406-409. [CrossRef]

130. Randrup, T.B.; Buijs, A.; Konijnendijk, C.C.; Wild, T. Moving beyond the Nature-Based Solutions Discourse: Introducing Nature-Based Thinking. Urban Ecosyst. 2020, 23, 919-926. [CrossRef]

131. Vera-Puerto, I.; Valdes, H.; Correa, C.; Agredano, R.; Vidal, G.; Belmonte, M.; Olave, J.; Arias, C. Proposal of Competencies for Engineering Education to Develop Water Infrastructure Based on "Nature-Based Solutions" in the Urban Context. J. Clean. Prod. 2020, 265, 121717. [CrossRef]

132. Wamsler, C.; Björn, H.; Falck, H.; Hanson, H.; Oskarsson, T. Beyond Participation: When Citizen Engagement Leads to Undesirable Outcomes for Nature-Based Solutions and Climate Change Adaptation. Clim. Chang. 2020, 158, 235-254. [CrossRef]

133. Frantzeskaki, N.; Vandergert, P.; Connop, S.; Schipper, K.; Zwierzchowska, I.; Collier, M.; Lodder, M. Examining the Policy Needs for Implementing Nature-Based Solutions in Cities: Findings from City-Wide Transdisciplinary Experiences in Glasgow (UK), Genk (Belgium) and Poznań (Poland). Land Use Policy 2020, 96, 104688. [CrossRef] 